\title{
A supply chain-oriented perspective to prevent future COVID-19: Mathematical model and experience of guaranteeing quality and safety of fresh agricultural products
}

Shi Yin ( $\nabla$ shyshi0314@163.com )

Hebei Agricultural University https://orcid.org/0000-0001-6885-7412

Lan Bai

Hebei Agricultural University

Runqing Zhang

Hebei Agricultural University

\section{Research Article}

Keywords: FAPs, COVID-19, Experience in epidemic prevention, Supply chain coordination, Cold chain logistics, Stackelberg game

Posted Date: July 19th, 2021

DOI: https://doi.org/10.21203/rs.3.rs-410784/v1

License: (c) (i) This work is licensed under a Creative Commons Attribution 4.0 International License.

Read Full License 


\section{A supply chain-oriented perspective to prevent future 3 COVID-19: Mathematical model and experience of 5 Shi Yin ${ }^{1,2^{*}}$, Lan Bai ${ }^{2}$ and Runqing Zhang ${ }^{2}$

\author{
School of Economics and Management, Harbin Engineering University, Harbin, 150001, China \\ 2 College of Economics and Management, Hebei Agricultural University, Baoding, 071000, China \\ * Correspondence: shyshi0314@163.com
}

\begin{abstract}
The COVID-19 outbreak has exposed deficiencies in the supply chain of FAPs, which have also increased their vulnerability. As the COVID-19 epidemic continues to develop, the effective supply of FAPs during the epidemic prevention and control period has become a key part of the response to the epidemic in metropolitan areas. Based on the game theory, this study constructed a three-level supply chain consisting of suppliers, TPL service providers and retailers to guarantee the supply of FAPs in metropolises in the context of COVID-19 epidemic. By Stackelberg principle game theory, the optimal epidemic prevention effort level, preservation effort level, wholesale price, retail price and optimal profit result in the supply chain dominated by supplier and retailer are respectively solved. In this study, in addition to the characteristics of FAPs such as easy loss and perishable, COVID-19 epidemic factors such as virus infection coefficient and epidemic prevention efforts were fully integrated into the model to ensure the effective supply of FAPs in metropolitan areas. The main research conclusions are as follows. (i) In the context of COVID-19, compared with the wholesale prices of FAPs, the level of preservation efforts and epidemic prevention efforts will have a greater impact on the retail prices of FAPs in metropolitan areas. (ii) When the supplier is in the dominant position, the sensitivity coefficient of the quality assurance effort level is positively correlated with the optimal profit of the supplier. Compared with other members, they have stronger control ability and decision-making ability, so that their profits are greater than those of other members. (ii) Compared with suppliers who are in the leading position of guarantee and supply, when FAPs retailers are in the leading position of guarantee and supply, TPL service providers have a higher level of epidemic prevention efforts and preservation efforts for FAPs. At the same time, the quality effort level, market demand and retail price are all greater under the retailer-led guarantee. (iv) The profit of FAPs retailers is affected by the sensitivity coefficient of preservation effort level, epidemic prevention effort level and dominant guarantee status.
\end{abstract}

Keywords: FAPs; COVID-19; Experience in epidemic prevention; Supply chain coordination; Cold chain logistics; Stackelberg game

\section{Introduction}

In 2002, the first case of SARS was found in Guangdong, China. According to a report released by the World Health Organization (WHO), as of August 7, 2003, there had been 8,422 cases of SARS worldwide, involving 32 countries and regions. The global death toll from SARS is 919 , with a fatality rate of nearly $11 \%$. The sudden disaster of SARS not only caused huge economic losses, but also had a profound impact on the life of metropolitan residents in terms of product supply, product demand and the way to realize them. Similarly, the sudden outbreak of coronavirus pneumonia has spread 
rapidly all over the world, causing great impact and harm to the production, life and even life of people in metropolises [1]. According to the latest who real-time statistics, as of 15:58 Central European time on 28 October 2020, there have been 43766,712 confirmed cases of COVID-19 globally and 1163,459 cumulative deaths. On The 28th, there were 404,159 new confirmed cases of COVID-19 worldwide and 5,780 new deaths. As the outbreak spreads, Figure 1 shows the number of existing confirmed cases of COVID-19 globally on 23 December 2020.

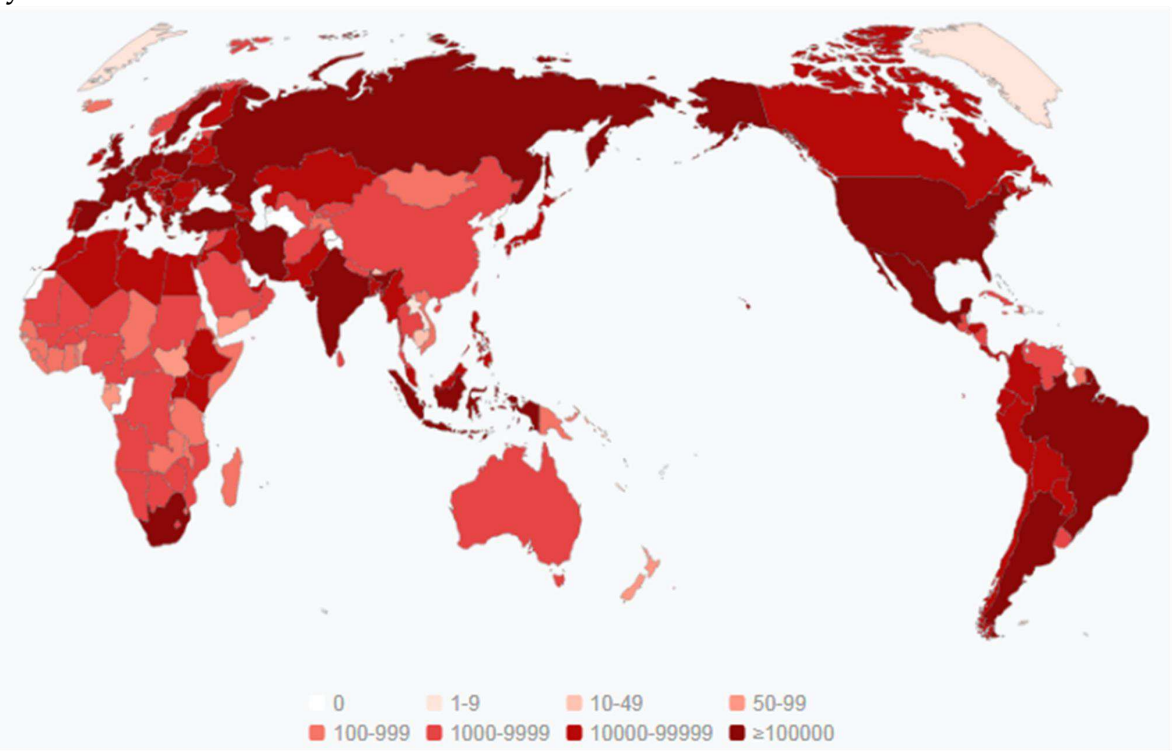

Figure 1. The global COVID-19 epidemic on 23 December 2020. (Note: Baidu's real-time big data report on COVID-19)

Figure 1 indicate a high probability of a second outbreak. At the same time, France again, Germany again sealed the city. These phenomena also indicate that the COVID-19 virus is sweeping the world in a big way this winter! COVID-19 has a serious impact on the lives of metropolitan residents, such as an unprecedented "lockdown". WHO has classified the COVID-19 outbreak as a public health emergency of international concern. There is no doubt that COVID-19 and SARS have seriously threatened the lives and health of metropolitan residents. In order to prevent the spread of infectious diseases, we must pay attention to this important aspect of urban planning, construction and management. It is necessary to add infectious disease prevention and control planning in the special planning of urban planning, and take measures for infectious disease prevention and control from the perspective of urban planning.

Novel Coronavirus nucleic acid positive test was found in seafood products from Wuhan Hunanhai Fresh Market to Beijing Xinfadi farmers' Market in early 2020. Subsequently, positive novel Coronavirus nucleic acid was detected in the packaging samples of some frozen South American white shrimp produced by the customs of Dalian, Xiamen and Qingdao in Ecuador. Table 1 shows the detection results of COVID-19 associated with fresh frozen products over the last 6 months. The novel Coronavirus epidemic prevention and control in Qingdao has found sufficient evidence chain in the world for the first time, which shows that it can be transmitted from irus to irus and survive for a long time under freezing conditions. The humid environment in the seafood market is conducive to the survival of the virus, and most seafood products require low temperature storage [2]. Low temperature is suited to novel Coronavirus survival. Viruses live longer in seafood markets and are more likely to infect people than in other places. In addition, because seafood markets are crowded, the number of people naturally infected is likely to be large. Once seafood products carry the virus, people associated with seafood markets are also more likely to become infected than the general population. 
Table 1. Novel Coronavirus detection results of imported fresh frozen products from many regions in China since July 2020.

\begin{tabular}{|c|c|}
\hline Event time & Event content \\
\hline July 10th & $\begin{array}{l}\text { Novel coronavirus was detected in three batches of frozen shrimp containers imported from Ecuador by Dalian } \\
\text { customs and Xiamen customs respectively. }\end{array}$ \\
\hline July 14th & $\begin{array}{l}\text { Some consumers in Pingxian City, Jiangxi province used to buy Ecuadorian frozen shrimp through } \\
\text { group-buying platform, while the inner wall and outer package of the same batch of products were tested } \\
\text { positive for nucleic acid from novel Coronavirus. }\end{array}$ \\
\hline July 15th & $\begin{array}{l}\text { Novel coronavirus nucleic acid test of some Ecuadorian frozen shrimp packaging was found positive in a frozen } \\
\text { warehouse in Western Chongqing logistics Park in Shapingba District, Chongqing. }\end{array}$ \\
\hline July 16th & $\begin{array}{l}\text { Yunnan province reported that novel Coronavirus nucleic acid tested positive in three samples of Ecuadorian } \\
\text { frozen shrimp from the outer surface of the packing cases. }\end{array}$ \\
\hline July 23th & $\begin{array}{l}\text { Novel coronavirus was detected in a number of samples from Dalian Kaiyang seafood refrigerator, processing } \\
\text { workshop, dormitory, cafeteria and environment. }\end{array}$ \\
\hline August 11th & $\begin{array}{l}\text { Novel coronavirus nucleic acid test results of package samples of frozen seafood products imported from Dalian } \\
\text { port by three enterprises in Yantai, Shandong province were positive. }\end{array}$ \\
\hline August 12th & $\begin{array}{l}\text { Novel coronavirus nucleic acid test on the packaging sample of Ecuadorean frozen shrimp imported from a } \\
\text { restaurant in } \mathrm{Wuhu} \text {, Anhui province was positive. }\end{array}$ \\
\hline August 12th & $\begin{array}{l}\text { Novel coronavirus nucleic acid tested positive for two samples of Brazilian frozen chickens submitted by The } \\
\text { Center for Disease Control and Prevention in Longgang District, Shenzhen. }\end{array}$ \\
\hline $\begin{array}{l}\text { September } \\
24 \text { th }\end{array}$ & $\begin{array}{l}\text { In Qingdao, 1,440 samples of cold-chain products and environmental samples were collected, and a total of } 51 \\
\text { samples were positive. }\end{array}$ \\
\hline
\end{tabular}

FAPs mainly refer to the primary products of vegetables, fruits, meat, eggs, milk and aquatic products, which are the main food sources in people's daily life [2,3]. Its fresh degree is the important standard that measures agricultural product value. The biggest drawback of fresh produce is that it is perishable. FAPs logistics is to ensure the safety and quality of FAPs in the delivery process from external environmental damage to reduce the loss of agricultural products. Cold chain logistics is the use of temperature control to protect its fresh characteristics. As the economy develops and the epidemic intensifies, the demand for agricultural products in the life of metropolis residents increases gradually. This also urges the market demand of FAPs such as vegetable, fruit and meat at present stage to expand continuously. However, the distribution of FAPs in China is extremely uneven. Inner Mongolia is rich in beef and mutton, and the fishing industry is concentrated in the coastal zone. Cold chain transportation in the fresh supply chain allows these local products to flow horizontally across the country and even globally. China's cold chain of FAPs is fragmented. Some cold-chain enterprises serve only one region, and some cold chain enterprises may serve a cold chain of trunk, long-distance transportation. Some are just deliveries that serve a particular city. The outbreak of the epidemic, the agricultural products of the transport chain has become very obvious. Moreover, it is difficult to meet the daily needs of metropolitan residents.

In general, fresh supply chain in China mainly presents the following characteristics. First, China's cold chain logistics system is not perfect, fresh loss rate is high. High loss rate and insufficient input of cold chain logistics facilities and equipment such as refrigerated trucks and warehouses in China. Laws and regulations of cold chain logistics and imperfect industry standards are closely related. By the end of 2018, compared with 1.76 refrigerated thermos cars per 1,000 people in the United States, the number in China is only 0.13 . Due to the lack of cold chain logistics technology and facilities and equipment, most FAPs supply chain in China covers a regionally based area, and the circulation radius of FAPs is small. In addition, China's fresh supply chain is too dispersed at both ends. On the one hand, fresh supply chain has long been very decentralized production and management, low concentration. On the other hand, the consumer market in China is characterized by diversified demands due to the dispersed residence and consumption market and the different dietary habits in different places. On the whole, China's FAPs supply chain chain long, more intermediate links. Due to 
the over-dispersed production and consumption markets, the organization of FAPs becomes more difficult, and the multi-level supply chain structure is hard to avoid. In this context, the increasing COVID-19 epidemic has a significant impact on the demand for FAPs among metropolitan residents.

It should be emphasized that cold chain FAPs transportation could easily become the carrier of novel Coronavirus due to appropriate temperature. Most viruses can survive for a long time at low temperatures. Both freezing and freezing give the virus a longer survival time. Because the virus has no cellular structure, the ice crystals created when it is frozen cannot kill it. Laboratories that make viruses often freeze them in freezers. After thawing, the virus is still infective. Cold chain is a very complex logistics system, involving a large number of people, as shown in Figure 2. Figure 2 shows the entire cold chain transportation system to meet the needs of metropolitan residents in the face of COVID-19. From the production and processing of food, to the cold storage, to the cold chain transport vehicles, containers, ships shipping, to the destination of the cold storage, and then through the destination of the cold chain transport vehicles to the market. Each step involves a large number of practitioners. If the outbreak is not over in the place where the food is produced, there is a risk that workers will become infected. Once a novel Coronavirus gets contaminated in one link of the whole fresh produce chain, the system's risk will be high. Many institutions and scholars believe that the source of the virus in the epidemic situation in Xinfadi of Beijing is most likely to be imported food in the cold chain of the regions with high epidemic incidence outside China, and they have proposed that the cold chain transport or novel coronavirus transmission approach. If fresh agricultural product carries the virus, it can easily be transported in the cold chain to large cities and even directly infect residents.

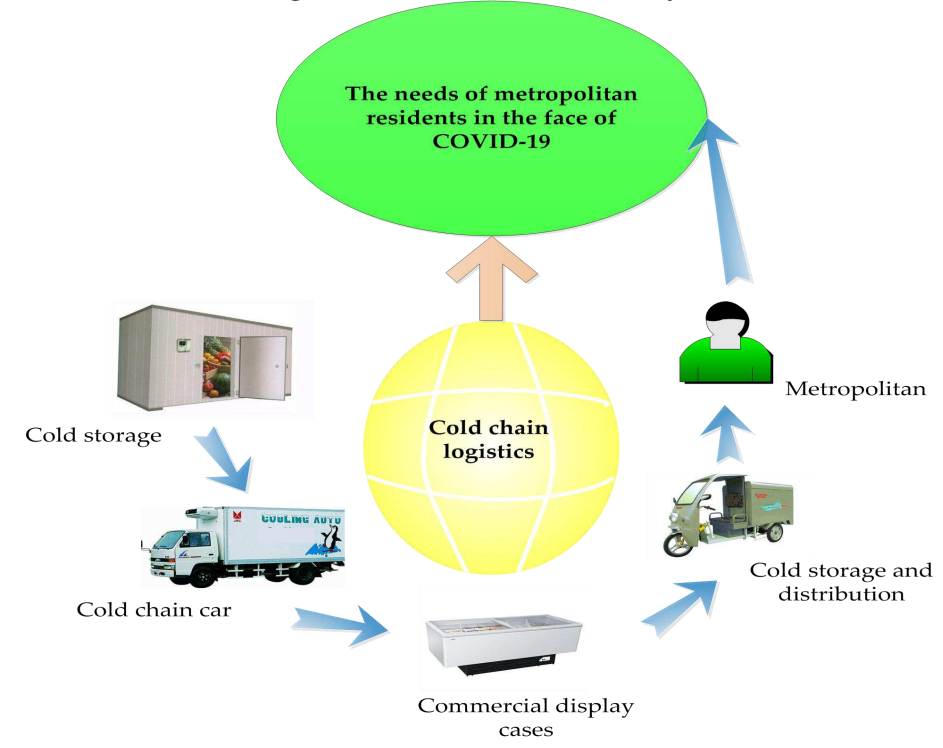

Figure 2. The entire cold chain transportation system to meet the needs of metropolitan residents in the face of COVID-19.

In recent years, public health emergencies and problems related to FAPs markets have been widely concerned in many cities. These cities have begun to open the market to clear or move the traditional market. For example, Beijing has closed or relocated the Dongdan Market, Xidan Market, Chongwenmen Market and Chaonei Market, which were once known as the four largest food markets in Beijing. The new land formed in response to the development of the metropolis is the "vegetable basket" of Beijing and the synonym of Chinese agricultural products. Xinfadi is the largest specialized agricultural wholesale market in Beijing and Even in Asia, covering an area equivalent to 170 football pitches. Xinfadi has made a great contribution to ensuring the basic livelihood of The people in Beijing. In the early days of market opening, it was even an 
advanced product of the market. Today, however, its problems are clear enough. Behind the dirty and disordered new place is the immaturity of urban agricultural and sideline product circulation system. Many wholesale markets are still in the stage of original stallholders and low-level operation, so it is urgent to bring the construction of standardized, green and intelligent wholesale markets into the scope of agricultural batch market governance. With the implementation of joint prevention and control measures, the COVID-19 epidemic in Beijing has been quickly and steadily brought under control.

The scenario of this study is set as the COVID-19 outbreak in July 2020 in Xinfa District of Beijing. This scenario mainly shows the COVID-19 outbreak in the metropolis (Beijing). On the one hand, in this context, it is different from the traditional market in the supply of FAPs in the "separate". The perishable nature of fresh products determines that the logistics process should be efficient and rapid. Therefore, TPL providers have been widely introduced to meet the communication and cooperation between all links of cold chain logistics and transportation of FAPs. How can suppliers, retailers and third-party cold chain logistics leverage their integration advantages to achieve traceability and verification of every link from sales to dining table, so as to ensure the safety of FAPs to the greatest extent? On the other hand, in such a future scenario, how to guarantee quality and safety of FAPs for future COVID-19 pandemic to satisfy metropolitan life? These two aspects are very interesting and need to be studied in depth to reveal the guarantee mechanism of fresh produce supply in this context and the effective supply of fresh produce for future urban response to epidemic diseases.

Based on the above analysis, this study first made a certain scenario hypothesis for the studied problem. Under the consideration of virus infection coefficient, epidemic prevention efforts and preservation efforts, a game model was established for FAPs supply chain in metropolis under the background of COVID-19, consisting of FAPs suppliers, TPL service providers and retailers. Stackelberg's master-subordinate game theory is used to solve the optimal preservation effort level, wholesale price, retail price and optimal profit result in the game model of supplier and retailer's dominant guaranteed supply chain respectively. On the one hand, this study reveals the effective supply mechanism of FAPs in metropolises in the context of COVID-19 epidemic; on the other hand, this study provides experience and reference for the future implementation of joint prevention and control of COVID-19 in metropolises. This study theoretically enriched the theoretical research content and research perspective of the three-level supply chain of FAPs, and practically provided guidance for the effective supply and supply of FAPs in metropolises in the context of COVID-19 epidemic.

The following design structure of this study is as follows. Based on the review of FAPs related literature, the guarantee mechanism of FAPs supply chain in metropolis is analyzed in Section 2. Section 3 shows the strategy of FAPs quality. Suppliers and retailers lead the quality control strategies of FAPs under guarantee respectively, which are studied in Section 4 and Section 5. A comparative analysis of fresh produce quality control strategies is presented in Section 6. Finally, Section 7 shows the conclusion of this research and the future research direction.

\section{Literature review and theoretical basis}

\subsection{Literature review}

\subsubsection{FAPs supply chain}

Fresh produce is a kind of perishable goods. The storage period of FAPs is short and there are different degrees of quality and quantity decay along with the time. The characteristics of fresh produce are usually characterized by uncertain output and demand, long lead times and relatively low marginal profit margins [2]. The circulation mode of FAPs can be divided into two types, namely single-channel supply chain and 
double-channel supply chain. In the context of COVID-19, the single-channel supply chain was designed as a research scenario in this study to effectively reduce unnecessary exposure. The single-channel supply chain is divided into two levels of FAPs supply chain and three levels of FAPs supply chain. Scholars have done a lot of research on the key factors of fresh produce supply chain. These studies often explore the operational problems of sowing, production, harvesting, transportation, distribution, inventory, sales and returns in the supply chain through key factors [3-32]. The aim of these studies is to optimize the operation efficiency of supply chain. Table 2 shows the recent research references of FAPs supply chain.

Table 2. Recent research references on supply chain of FAPs.

\begin{tabular}{|c|c|c|c|c|}
\hline $\begin{array}{l}\text { Supply chain } \\
\text { structure }\end{array}$ & $\begin{array}{l}\text { Supply chain } \\
\text { process }\end{array}$ & Critical factors & Research objectives & References \\
\hline Producer - seller & Harvest - sales & Quality loss & $\begin{array}{l}\text { The mixed response model after } \\
\text { harvest can effectively reduce the } \\
\text { quality loss of supply chain. }\end{array}$ & $\begin{array}{l}\text { Blackburn } \\
\text { and } \\
\text { Scudder [3] }\end{array}$ \\
\hline $\begin{array}{l}\text { Manufacturer - } \\
\text { Distributor }\end{array}$ & $\begin{array}{l}\text { Production - } \\
\text { transportation - } \\
\text { sales }\end{array}$ & Quantity and quality loss & $\begin{array}{l}\text { The design of incentive mechanism } \\
\text { can realize the coordination of } \\
\text { interests of both sides. }\end{array}$ & $\begin{array}{l}\text { Cai et al. } \\
\text { [4] }\end{array}$ \\
\hline $\begin{array}{l}\text { Manufacturer - } \\
\text { TPL - distributor }\end{array}$ & $\begin{array}{l}\text { Production - } \\
\text { transportation - } \\
\text { sales }\end{array}$ & Quantity and quality loss & $\begin{array}{l}\text { TPL has a significant impact on } \\
\text { supply chain performance. }\end{array}$ & $\begin{array}{l}\text { Cai et al. } \\
\text { [5] }\end{array}$ \\
\hline $\begin{array}{l}\text { Producer - } \\
\text { export - local } \\
\text { market }\end{array}$ & $\begin{array}{l}\text { Production - } \\
\text { transportation - } \\
\text { sales }\end{array}$ & The number of loss & $\begin{array}{l}\text { Replenishment by order and } \\
\text { replenishment by stock will have } \\
\text { different effects on product loss. }\end{array}$ & $\begin{array}{l}\text { Cai and } \\
\text { Zhou[6] }\end{array}$ \\
\hline Producer - seller & Production - sales & $\begin{array}{l}\text { Uncertainty about output, } \\
\text { demand and prices }\end{array}$ & $\begin{array}{l}\text { To manage uncertainty, vendors need } \\
\text { to strike a balance between resource } \\
\text { inputs and revenue. }\end{array}$ & $\begin{array}{l}\text { Gokarn et } \\
\text { al. [7] }\end{array}$ \\
\hline $\begin{array}{l}\text { Fresh } \\
\text { e-commerce - } \\
\text { offline physical } \\
\text { stores }\end{array}$ & $\begin{array}{l}\text { Online - offline } \\
\text { sales channels }\end{array}$ & Circulation channel, loss & $\begin{array}{l}\text { Online and offline dynamic pricing } \\
\text { strategies influence each other. }\end{array}$ & He et al. [8] \\
\hline $\begin{array}{l}\text { Manufacturer - } \\
\text { processing } \\
\text { center - } \\
\text { distributor }\end{array}$ & $\begin{array}{l}\text { Harvest - } \\
\text { processing - } \\
\text { distribution }\end{array}$ & $\begin{array}{l}\text { Seasonality, demand and } \\
\text { harvest uncertainty, loss }\end{array}$ & $\begin{array}{l}\text { Customization of supply chain } \\
\text { around the uncertainty of FAPs can } \\
\text { improve the operation performance of } \\
\text { supply chain. }\end{array}$ & $\begin{array}{l}\text { Jonkman et } \\
\text { al. [9] }\end{array}$ \\
\hline $\begin{array}{l}\text { Supplier - TPL - } \\
\text { retailer }\end{array}$ & $\begin{array}{l}\text { Supply - } \\
\text { transportation - } \\
\text { sales }\end{array}$ & Quantity and quality loss & $\begin{array}{l}\text { The revenue-sharing contract and the } \\
\text { fresh-keeping effort level sharing } \\
\text { contract can realize the supply chain } \\
\text { coordination and Pareto } \\
\text { improvement. }\end{array}$ & $\begin{array}{l}\text { Ma et al. } \\
\quad[10]\end{array}$ \\
\hline Supplier - Seller & Production - sales & $\begin{array}{l}\text { The cost in quantity and } \\
\text { quality }\end{array}$ & $\begin{array}{c}\text { The design of revenue-sharing and } \\
\text { technology investment contract } \\
\text { sharing can achieve coordination. }\end{array}$ & $\begin{array}{l}\text { Mohamma } \\
\text { di et al. [11] }\end{array}$ \\
\hline $\begin{array}{l}\text { Manufacturer - } \\
\text { Retailer }\end{array}$ & $\begin{array}{l}\text { Production - } \\
\text { distribution - } \\
\text { inventory }\end{array}$ & $\begin{array}{l}\text { The quality of whipped } \\
\text { consumption }\end{array}$ & $\begin{array}{l}\text { A method of building quality loss } \\
\text { model for production and distribution } \\
\text { decision is proposed. }\end{array}$ & $\begin{array}{l}\text { Rong et al. } \\
\text { [12] }\end{array}$ \\
\hline $\begin{array}{l}\text { Supplier - } \\
\text { Retailer }\end{array}$ & $\begin{array}{l}\text { Production - } \\
\text { transportation - } \\
\text { sales }\end{array}$ & $\begin{array}{l}\text { Random output and } \\
\text { random demand }\end{array}$ & $\begin{array}{l}\text { The contract is designed to increase } \\
\text { the profit of supply chain members } \\
\text { under controllable transport time. }\end{array}$ & $\begin{array}{l}\text { Su et al. } \\
\text { [13] }\end{array}$ \\
\hline $\begin{array}{l}\text { Distributor - } \\
\text { logistics service } \\
\text { provider }\end{array}$ & $\begin{array}{l}\text { Transportation - } \\
\text { Sales }\end{array}$ & Quantity and quality loss & $\begin{array}{l}\text { The power structure affects contract } \\
\text { design, enterprise decision behavior } \\
\text { and system performance. }\end{array}$ & $\begin{array}{l}\text { Wu et al. } \\
\text { [14] }\end{array}$ \\
\hline
\end{tabular}




\begin{tabular}{|c|c|c|c|c|}
\hline $\begin{array}{l}\text { Manufacturer - } \\
\text { Distributor }\end{array}$ & $\begin{array}{l}\text { Production - } \\
\text { transportation - } \\
\text { sales }\end{array}$ & The number of loss & $\begin{array}{l}\text { Using the pull model can make both } \\
\text { parties perform better, and the } \\
\text { introduction of FIPF strategy can } \\
\text { achieve pareto improvement. }\end{array}$ & $\begin{array}{l}\text { Xiao and } \\
\text { Chen[15] }\end{array}$ \\
\hline $\begin{array}{l}\text { Supplier - TPL - } \\
\text { retailer }\end{array}$ & $\begin{array}{l}\text { Production - } \\
\text { transportation - } \\
\text { sales }\end{array}$ & The number of loss & $\begin{array}{l}\text { Cold chain service price and service } \\
\text { sensitivity will affect the profit of } \\
\text { supply chain members. }\end{array}$ & $\begin{array}{l}\text { Yu and } \\
\text { Xiao[16] }\end{array}$ \\
\hline $\begin{array}{l}\text { Supplier - TPL - } \\
\text { retailer }\end{array}$ & $\begin{array}{l}\text { Supply - } \\
\text { production - sales }\end{array}$ & $\begin{array}{l}\text { Random output and } \\
\text { random demand, quality } \\
\text { loss }\end{array}$ & $\begin{array}{l}\text { The wholesale price and logistics } \\
\text { service price clearing contract are } \\
\text { introduced in order to realize supply } \\
\text { chain coordination. }\end{array}$ & $\begin{array}{l}\text { Feng et al. } \\
\quad[17]\end{array}$ \\
\hline $\begin{array}{l}\text { Supplier - } \\
\text { Retailer }\end{array}$ & Supply - Sales & Quality loss & $\begin{array}{l}\text { Purchase price contract and wholesale } \\
\text { price - fresh-keeping cost sharing } \\
\text { contract can promote the supply chain } \\
\text { to improve fresh-keeping. }\end{array}$ & $\begin{array}{l}\text { Wang and } \\
\text { Dan, [18] }\end{array}$ \\
\hline $\begin{array}{l}\text { Producer - } \\
\text { wholesale } \\
\text { market }\end{array}$ & $\begin{array}{l}\text { Production - } \\
\text { transportation - } \\
\text { sales }\end{array}$ & $\begin{array}{c}\text { The cost in quantity and } \\
\text { quality }\end{array}$ & $\begin{array}{l}\text { Different business models have a } \\
\text { great impact on the decision-making } \\
\text { and coordination mechanism of } \\
\text { supply chain members. }\end{array}$ & $\begin{array}{l}\text { Xiao et al. } \\
\text { [19] }\end{array}$ \\
\hline $\begin{array}{l}\text { Manufacturer - } \\
\text { Distributor }\end{array}$ & Production - sales & $\begin{array}{c}\text { The cost in quantity and } \\
\text { quality }\end{array}$ & $\begin{array}{l}\text { Adjusting the strategy of freshness } \\
\text { preservation effort can affect the } \\
\text { benefit of both supply chain members. }\end{array}$ & $\begin{array}{l}\text { Zheng et al. } \\
\text { [20] }\end{array}$ \\
\hline $\begin{array}{l}\text { Manufacturer - } \\
\text { Retailer }\end{array}$ & $\begin{array}{l}\text { Manufacturing - } \\
\text { Sales }\end{array}$ & $\begin{array}{l}\text { Strategic consumer } \\
\text { behavior }\end{array}$ & Revenue sharing and wholesale price & $\begin{array}{l}\text { Yan et al. } \\
\qquad[21]\end{array}$ \\
\hline $\begin{array}{l}\text { Supplier - } \\
\text { Retailer }\end{array}$ & Supply - Sales & $\begin{array}{l}\text { The value loss of fresh } \\
\text { agri-products under } \\
\text { different transportation } \\
\text { modes }\end{array}$ & $\begin{array}{l}\text { Improving the utilization rate of cold } \\
\text { chain transportation of fresh } \\
\text { agri-products. }\end{array}$ & $\begin{array}{l}\text { Yan et al. } \\
\text { [22] }\end{array}$ \\
\hline $\begin{array}{l}\text { Manufacturer - } \\
\text { Distributor }\end{array}$ & Production - sales & $\begin{array}{l}\text { Ultrasound-assisted } \\
\text { cleaning }\end{array}$ & Improving food safety for consumers & $\begin{array}{c}\text { Azam et al. } \\
{[23]}\end{array}$ \\
\hline $\begin{array}{l}\text { Supplier - } \\
\text { Retailer }\end{array}$ & Supply - Sales & $\begin{array}{l}\text { Freshness-keeping effort, } \\
\text { the price, and greenness } \\
\text { improvement level }\end{array}$ & $\begin{array}{l}\text { Cost sharing considering } \\
\text { freshness-keeping effort }\end{array}$ & $\begin{array}{l}\text { Wang et al. } \\
\quad[24]\end{array}$ \\
\hline $\begin{array}{l}\text { Supplier - } \\
\text { Retailer }\end{array}$ & Supply - Sales & $\begin{array}{l}\text { The sensitivity coefficient } \\
\text { of market freshness and } \\
\text { the freshness effort cost } \\
\text { coefficient, }\end{array}$ & $\begin{array}{c}\text { Optimal operational and financing } \\
\text { strategies for medium-sized } \\
\text { enterprises }\end{array}$ & $\begin{array}{l}\text { Yan et al. } \\
\text { [25] }\end{array}$ \\
\hline $\begin{array}{l}\text { Fresh } \\
\text { e-commerce - } \\
\text { TPL - offline } \\
\text { physical stores }\end{array}$ & $\begin{array}{l}\text { Online - shipping } \\
\text { - offline }\end{array}$ & $\begin{array}{c}\text { Different contract } \\
\text { coordination mechanisms }\end{array}$ & $\begin{array}{l}\text { Achieving the coordination of } \\
\text { three-layer fresh agricultural product } \\
\text { supply chain and maximize profit }\end{array}$ & $\begin{array}{l}\text { Song and } \\
\mathrm{He},[26]\end{array}$ \\
\hline
\end{tabular}

As can be seen from Table 2, the traditional production and marketing supply chain structure composed of "production or supplier - retailer" is still the focus of current research [27]. Therefore, the link involved in most studies is "production or supply sales". E-commerce marketing model is now more and more respected in some research. These studies involve factors such as live broadcast marketing and promotion. At the same time, there are also some studies on the introduction of transport links, the study of "manufacturers - logistics enterprises - retailers" consisting of the production, transport and sales supply chain. These studies discussed the impact of key factors such as transportation price, transportation time, service quality and service level on the loss of FAPs. In terms of the key influencing factors, the quality and quantity loss characteristics of FAPs and the uncertainty of output and demand are still the main 
entry points of most current studies. In terms of the loss of FAPs, the existing literature mostly uses the loss rate/effective supply rate and other parameters to describe the quantity loss characteristics of FAPs. For example, Xiao and Chen [14] studied the time-varying quantity loss function. Some literatures used freshness to express its quality/value loss characteristics. For example, Feng et al. [16] studied the freshness function form that depends on logistics service level. On this basis, Wang and Dan [17] discussed the function case that both declination with time and depend on logistics service level. In addition, other studies further consider the case of double loss. For example, Cai [4], Su et al. [12] and Xiao et al. [18] all considered the impact of transportation time on loss and study the double loss function in time-varying form. Cai et al. [3], Ma et al. [9], Wu et al. [13] and Mohammadi et al. [10] discussed the double loss function that depends on the level of preservation effort for different supply chain structures. In the aspect of random output, the coupling between random factors such as output and demand is the difficulty in discussing this kind of problem. The coupling phenomenon can be simplified by referring to common product supply chain and introducing practical operation strategy. Among them, most of the two strategies are Accept-all and Satify-all. Accept-all forces the retailer to accept the full output of the manufacturer, generally by assuming that the retailer's order volume is large enough, such as Giiler and Keskin [28], and Li et al. [29] adopted this strategy. Satify-all, by contrast, forces producers to meet retailers' entire orders. This can be achieved by setting up a spot market with unlimited supply, such as He and Zhang [30], and Hu et al. [31] all made this assumption. From the point of view of improving the supply chain operation efficiency, the design of contract mechanism to improve the supply chain operation efficiency of FAPs is still the focus of current research. In addition, a few studies hold that the supply chain efficiency can be improved by tailoring supply chain for FAPs or adopting new production and marketing mode (He et al. [7] and Jonkman et al. [8]). Xu studied the inventory cost of a three-level FAPs inventory system [32].

\subsubsection{Supply chain emergency management}

Natural disasters, sudden accidents and public health events have great impact on enterprise and supply chain management. Emergency is the personnel or equipment and other key resources, in a specific state of serious deviation from the original normal situation and plan, so it must be responded to and adjusted. And the impact that can make such a state appear is called emergency events [33]. Emergencies directly lead to supply chain coordination or the original plan is no longer feasible, and then affect the production decision of the supply chain and affect the supply chain revenue. How to make timely and accurate production decision arrangement in case of emergency is a long-term problem that needs to be solved in the field of emergency management.

The concept of emergency management was proposed by Clausen et al [34] in OR/MS Today in 2001. Huang et al [35] studied supply chain emergency management based on symmetric information and index demand. Wu et al [36] studied the supply chain emergency coordination problem in which demand and retailer purchase cost are simultaneously disturbed. Lin et al [37] used the insurance contract to study the supply chain coordination. Rabbani et al [38] established a binary tree option pricing model and found that the initial purchase amount of the purchaser is negatively correlated with the strike price of the option. Liang et al [39] established the pricing model of emergency materials procurement by using option contracts and pointed out that there is a flexible option price range that can benefit both the government and suppliers. Lodree [40] and Taskin [41] introduced the dynamic newsboy model to determine the optimal inventory level of emergency supplies in view of the uncertainty of emergency supplies demand caused by sudden disasters. Saputra et al [42] studied the impact of the average interval of sudden disasters on the emergency drug reserve and established the emergency drug reserve model. Soldmani studied the pricing strategies of centralized and decentralized dual-channel supply chains, and the model was solved by using the KT condition [43]. 
Zhang found that the coordination contract of dual-channel supply chain can not only realize the comprehensive profit of supply chain, but also alleviate the channel conflict under the disturbance [44]. Wu et al [45] discussed the impact of emergencies on centralized and decentralized supply chains under the condition that the market demand, ordering cost of retailers and product transportation time are disturbed simultaneously.

In addition, some scholars also emphasize the importance of quantitative flexible contracts, believing that its main purpose is to reduce the potential risks in the process of product supply. Qi et al [46] took the lead in the systematic study of a supply chain consisting of a supplier and a retailer, and designed quantity discount contracts based on symmetric information and linear demand to coordinate emergencies. Knoblich and Heavey [47] used quantitative elastic contracts to match demand and capacity in the semiconductor industry. Chen et al [48] studied the coordination strategy of quantitative elastic contract under uncertain market size based on the supply chain system of single manufacturing and multiple retailers. Bicer and Hagspiel [49] studied that suppliers adopt quantitative flexible contracts to deal with supply chain risks. He and Yang [50] reduced the buyer's profit risk in the supply chain through the quantity elastic contract under the conditions of deterministic and stochastic demand. Nikkhoo et al [51] studied the coordination of relief materials in humanitarian logistics and used the quantity flexible contract to coordinate the procurement activities in the three-level supply chain.

\subsection{Theoretical basis}

\subsubsection{The operation mechanism of FAPs supply chain}

The supply chain of FAPs can be divided into five operation modes with agricultural cooperatives, processing enterprises, wholesale markets of agricultural products, supermarkets and online platforms as the core. The agricultural cooperative model is centered on connecting farmers and markets. Although this mode enhances the discourse power of farmers, the cooperative relationship between agricultural cooperatives and farmers is not stable enough to complete the trans-regional transfer and delivery of FAPs. The mode of processing enterprise is that the agricultural product processing enterprise distributes the processed FAPs to the sales demand point. Under this mode, it is beneficial for the processing enterprises to build brand and improve consumer satisfaction. However, processing enterprises need to build their own logistics facilities and invest a lot of money. The wholesale market model of agricultural products is the main way to supply FAPs for urban residents in China. The wholesale market of agricultural products has a strong distribution function, but its supporting facilities are not complete, which aggravates the loss of FAPs and reduces the logistics efficiency. The supermarket model forms a stable purchasing relationship by taking advantage of its advantages in market information, operation and management, etc., which increases consumers' trust in the supermarket's FAPs. However, due to the large investment in logistics infrastructure, no matter the supermarket chooses the self-logistics distribution system or the third-party logistics distribution system, the logistics cost is high. The modes of e-commerce, Wechat business and live-streaming platform omit the intermediate wholesale link, thus making the circulation of FAPs more smooth. However, the information about FAPs advertised by e-commerce is difficult to distinguish between true and false, and the quality of FAPs is also uneven.

To improve the circulation efficiency of FAPs, this paper improves the supply chain model of FAPs based on the intelligent environment of big data, as shown in Figure 3. The core values of FAPs supply chain innovation driven by big data technology include digital management of channel sales business, omni-channel collaborative retail, and digital intelligence of whole-process business processing. Based on the platform support of supply chain, big data intelligent technology can radiate more small platforms and provide entrepreneurial opportunities for more manufacturers and retailers. 


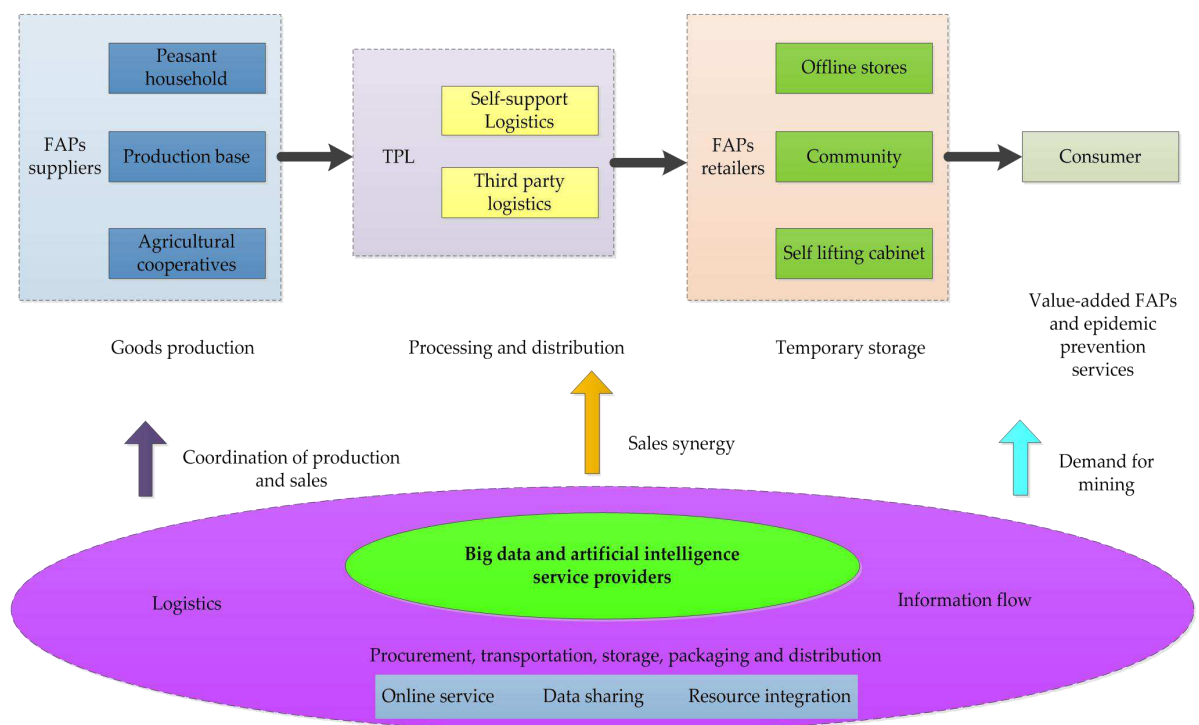

Figure 3. The FAPs supply chain model based on big data intelligence.

The supply chain model of FAPs based on big data shown in Figure 3 is different from the traditional supply chain of FAPs. This model is based on information technology and runs through the whole process of supply, circulation and sales of FAPs. Through the mode of e-commerce data platform, multiple members such as fresh e-commerce, FAPs producers, logistics service providers, sales demand points and consumers are connected. The Internet, big data, cloud computing and other methods are used to ensure the flow and smoothness of information and realize data sharing. This method broadens the source channels of FAPs in the whole supply chain. In the upper reaches of the supply chain are producers of FAPs, including farmers, agricultural production bases, agricultural cooperatives and so on. Fresh produce producers are mainly engaged in fresh produce stocking production and other business activities. The cooperation between self-operation and third-party logistics can optimize the warehousing and distribution mode. Enterprises can reduce costs and improve efficiency by jointly establishing distribution centers and using the same distribution system. The sales demand point can complete the temporary storage and display of FAPs and other business activities, which can solve the "last kilometer" problem of FAPs distribution. Business coordination among members of the supply chain, including goods preparation and production, processing and distribution, temporary storage and other links of close cooperation. Business collaboration based on big data intelligence can quickly and accurately provide FAPs suitable for consumers and improve consumer satisfaction. Consumers log on to the big data platform through a variety of clients and transmit the demand information of FAPs to fresh e-commerce companies. Fresh e-commerce suppliers share the demand information with FAPs producers, logistics service providers and sales demand points through the e-commerce platform system. Producers of agricultural products can stock goods according to the needs of consumers, which reduces the supply risk of producers and also reduces the cost of overstocking of agricultural products. The combination of self-support and third-party logistics is used to deliver the products to consumers through multiple points of demand. In the whole process, all members of the supply chain are closely connected based on big data intelligence, so as to effectively control the quality of FAPs.

\subsubsection{The emergency mechanism of FAPs supply chain}

Under the impact of the epidemic, the supply chain of FAPs is not coordinated and smooth. On the one hand, urban consumers face structural supply constraints and lack of confidence in the panic buying and hoarding, which in turn drives up prices. On the one hand, fresh products in some rural areas are unmarketable, and some livestock and 
poultry products cannot be sold. Social isolation and downtime trigger the risk of supply chain disruption. Social isolation prevents employees from returning in time, and underwork leads to slaughtering of livestock and poultry. Pig, poultry meat, poultry eggs, seed chick, commodity chick and other livestock and poultry products can not be sold in a timely manner, the pressure column phenomenon is serious. At the same time, due to the shortage of rework personnel in agricultural production areas, farmers cannot finish picking and packing FAPs in a short time. The measures taken to close the city have a great impact on the external logistics transportation of the supply chain. The closure measures mainly affect the land transport, and traffic control measures are adopted in many places. Some rural areas have even cut off road traffic, making it impossible for some areas to ship fresh produce. Emergencies are characterized by abruptness, uncertainty and serious consequences. Once an outbreak occurs, it is necessary to acquire professional manpower, facilities, technology, information and other resources within a short period of time to effectively control and deal with the emergency. In this study, Figure 4 shows the emergency mechanism of FAPs supply chain based on big data intelligence.

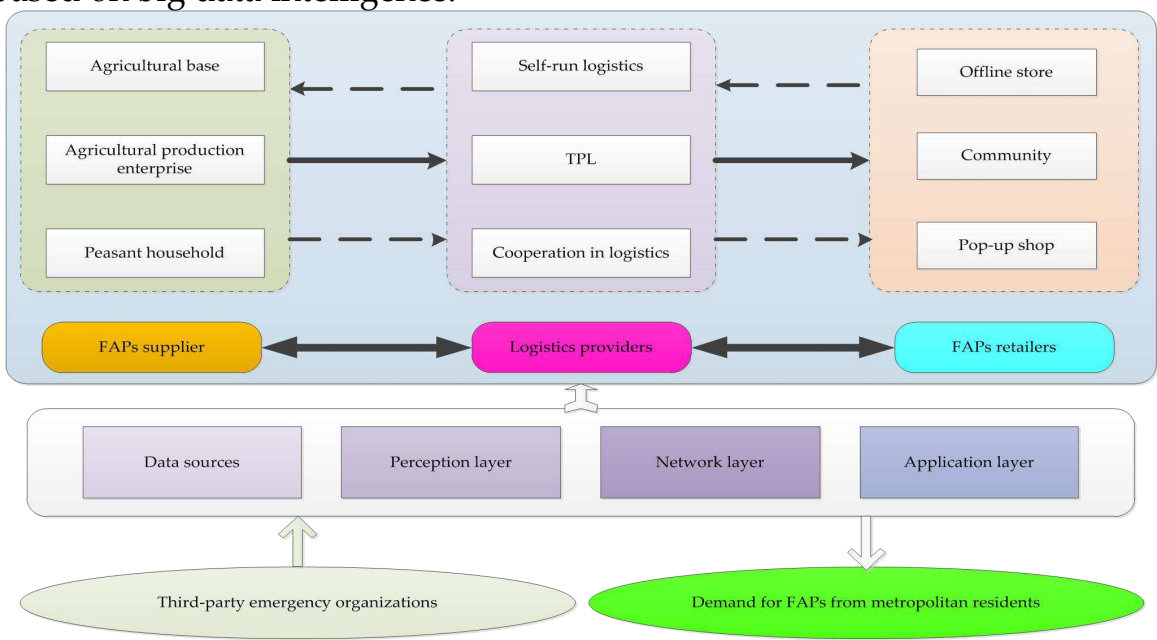

Figure 4. The emergency mechanism of FAPs supply chain based on big data intelligence.

Figure 4 shows that the FAPs information sharing platform built by artificial intelligence, Internet of Things and other technologies is utilized, which can quickly organize the whole process from production to sales of FAPs. This mode is conducive to FAPs supply chain members to complete a series of operations such as procurement, sales, logistics and finance. In addition, this model can also effectively reduce the risks existing in the supply chain of FAPs, thus promoting the improvement of FAPs efficiency and the reduction of costs. Big data intelligence drives FAPs supply chain platform to connect the collection of retailers and suppliers to help them dig customer demand. Big data intelligence is utilized to facilitate the platform to coordinate FAPs logistics operation, so as to complete customized services to customers. The innovation of this model lies in the realization of low cost and fast response of FAPs supply chain operation, and to meet the diverse needs of metropolitan consumers. This paper proposes a third party emergency mode based on FAPs emergency. A third party is an organization established by the government, enterprises or both to deal with emergencies of FAPs. From the perspective of emergency management, the third party has the professional advantages, resource advantages and cost advantages in dealing with emergencies. For example, TPLs have a dedicated emergency case base, professional emergency management personnel, emergency facilities and information network, and can provide customers with efficient emergency services. When COVID-19 occurs, if the farmers' alliance is unable to respond, it can be outsourced to a professional third party emergency response organization. Third party resources are 
utilized to minimize the loss caused by emergencies. Especially in public health emergencies, third-party emergency organizations can take advantage of their professional advantages to provide farmers with low-cost and efficient emergency services. The third party emergency organization provides the sales network and sales channels of FAPs in time, which can not only help the fruit farmers to deal with the unsalable events effectively, but also guarantee the supply of FAPs in the metropolis.

\section{Scenario and model of fresh agricultural product preservation strategy}

FAPs have the characteristics of easy metamorphism and perishability. Compared with normal times, under the COVID-19 epidemic, the logistics service providers of FAPs have relatively high requirements on anti-virus level and preservation level. The cold chain logistics provided by the third-party logistics service providers can not only greatly reduce the loss of FAPs in terms of quality and quantity in the process of transportation, storage, distribution and sales, but also greatly improve the anti-virus level of FAPs. In the context of COVID-19, third-party logistics not only provides an important guarantee for the distribution efficiency of FAPs, but also guarantees the quality and safety of FAPs. In addition, third parties are at risk of contracting the COVID-19 virus during the distribution of fresh produce.

\subsection{Preservation scenario}

In this study, a metropolitan outbreak of new crown pneumonia was set as a scenario. Good epidemic prevention effect has been maintained outside the metropolitan area, and this effect is that the new crown pneumonia epidemic has been effectively controlled. Under such circumstances, how to ensure the quality and safety of FAPs in metropolitan areas is a problem to be solved in this study. In this study, a three echelon supply chain composed of a single supplier, a single TPL service provider and a single retailer was used to ensure the quality and safety of FAPs in metropolitan areas in the case of sudden new crown pneumonia. The specific operation process to protect the FAPs in metropolis in the case of sudden new crown pneumonia is the process in which the supplier of FAPs determines the wholesale price $p_{w}$ of FAPs based on the unit cost $c_{w}$ of FAPs, the demand $D$ of FAPs, and receives the total payment from the retailer of FAPs. A fresh produce retailer determines the retail price $p_{r}$ of fresh produce. The demand for FAPs in the life of metropolitan residents is affected by the retail price $p_{r}$ and freshness $\theta$ of FAPs. TPL service providers provide FAPs cold chain transport service. The unit cost is $c_{l}$, and the freshness preservation effort level and epidemic prevention effort level are $e_{1}$ and $e_{2}$ respectively. A certain freshness preservation and epidemic prevention cost $C$ is generated. The prices of FAPs preservation and epidemic prevention services charged by the TPL service provider to the retailer are $P_{l 1}$ and $P_{l 2}$ respectively. Different Stackelberg master-slave game models were constructed according to the situation that suppliers and retailers of FAPs are in the dominant position of guaranteed supply. In this study, Figure 5 shows the quality and safety oriented strategy of FAPs in metropolis under the participation of third-party logistics. 

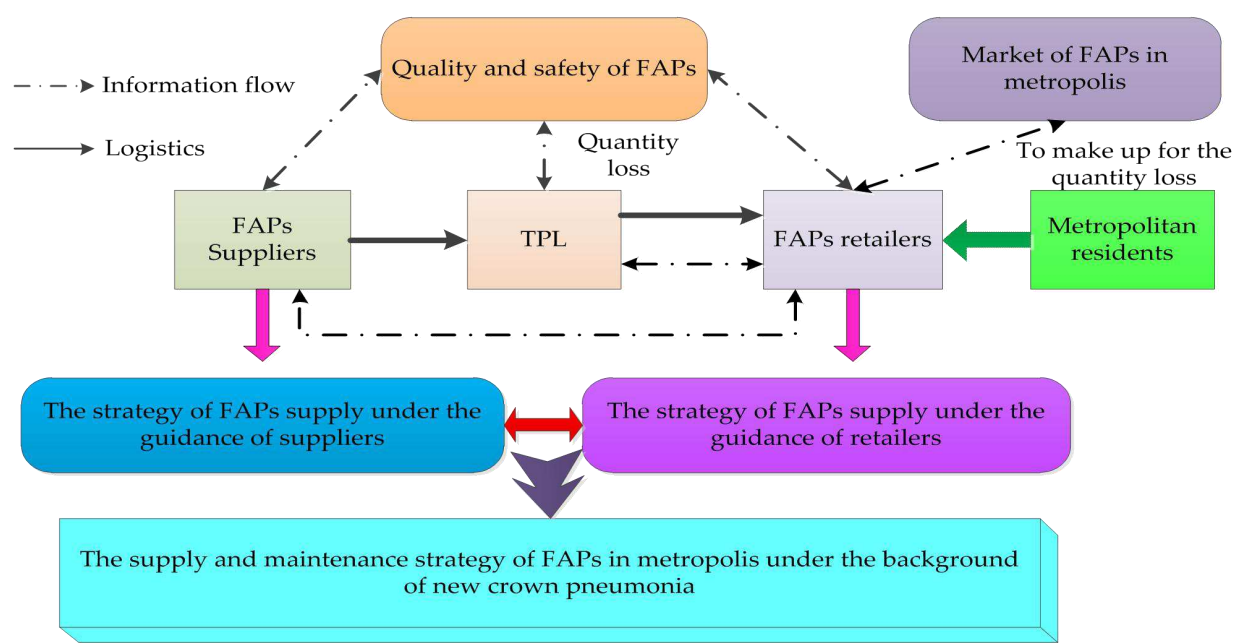

Figure 5. The quality and safety oriented strategy for FAPs in metropolis under the participation of third-party logistics.

In the context of the new crown pneumonia epidemic, the short-term interruption of the cold chain supply chain of FAPs has an impact on both ends of supply and demand. The outbreak exposed the vulnerability of the existing agricultural supply chain. After long-distance transportation, FAPs will deteriorate to a certain extent. This deterioration is not only reflected in the deterioration of the quality of FAPs caused by the decrease in the level of freshness, but also in the reduction in the quantity caused by the prior treatment due to putrefaction and deterioration. This will inevitably result in the number of FAPs arriving at the retailers less than the ordered quantity, which is the physical loss. Affected by the new crown pneumonia and other factors, the loss rate of fresh products was higher than the previous transportation situation. Moreover, due to the sudden occurrence of new crown pneumonia in metropolis, FAPs transported through the cold chain should be protected against the new crown pneumonia virus. The third party logistics service providers invest in preservation and epidemic prevention, including the use of professional cold chain equipment, advanced cold chain technology and effective epidemic prevention strategies. These strategies provide professional cold chain logistics services for FAPs, which can reduce the deterioration of FAPs and ensure the safety of FAPs to a certain extent. Due to the quantity loss of FAPs, the quantity of FAPs arriving at retailers will be less than the ordered quantity. Therefore, it is assumed that there is a spot market in which suppliers of FAPs can purchase sufficient FAPs from the market at the market price to replace the raw and FAPs that have been decomposed and deteriorated during transportation.

Based on the above analysis, the relevant symbol and variable descriptions are shown in Table 3.

Table 3. Model symbol for the quality assurance strategy of FAPs in Metropolis.

\begin{tabular}{|c|c|c|}
\hline Symbol type & Symbol form & Symbolic meaning \\
\hline \multirow{8}{*}{ Parameter } & $a$ & Demand scale of FAPs in Metropolis \\
\hline & $b$ & Sensitivity of demand for FAPs to retail price in Metropolis \\
\hline & $\beta$ & $\begin{array}{l}\text { Sensitivity of the demand for FAPs in metropolis to the level of preservation and } \\
\text { epidemic prevention efforts }\end{array}$ \\
\hline & $c_{w}$ & Unit production cost of FAPs of suppliers \\
\hline & $c_{l}$ & Unit fresh agricultural product service cost of TPL \\
\hline & $p_{l i}, i=1,2$ & Fresh keeping and epidemic prevention price of unit FAPs of TPL \\
\hline & $t$ & Market price of FAPs in Metropolis \\
\hline & $L_{i}, \quad i=1,2$ & Quantity loss rate and virus infection coefficient \\
\hline
\end{tabular}




\begin{tabular}{|c|c|c|}
\hline & $\theta$ & Quality assurance of FAPs \\
\hline & $\theta_{0 i}, \quad i=1,2$ & Initial fresh keeping level and initial epidemic prevention level \\
\hline \multirow{7}{*}{$\begin{array}{l}\text { Decision } \\
\text { variables }\end{array}$} & $C$ & $\begin{array}{c}\text { Quality assurance cost of cold chain transportation provided by TPL service } \\
\text { provider }\end{array}$ \\
\hline & $D$ & Demand for FAPs in Metropolis \\
\hline & $\sigma$ & Infection coefficient of new coronavirus \\
\hline & $\delta$ & Increased prices of fresh produce retailers \\
\hline & $e_{i}, \quad i=1,2\left(0<e_{i}<1\right)$ & $\begin{array}{l}\text { The level of fresh keeping and epidemic prevention efforts of FAPs contributed } \\
\text { by TPL }\end{array}$ \\
\hline & $p_{w}$ & Wholesale price of unit FAPs of suppliers \\
\hline & $p_{r}$ & Retail price of unit FAPs of retailers \\
\hline \multirow{3}{*}{$\begin{array}{l}\text { Objective } \\
\text { variable }\end{array}$} & $\pi_{l}$ & Profit of TPL \\
\hline & $\pi_{w}$ & Profit of FAP suppliers \\
\hline & $\pi_{r}$ & Profit of FAP retailers \\
\hline
\end{tabular}

\subsection{Preservation model}

Assumption 1. In the context of COVID-19, members of the supply chain at all levels of FAPs in metropolitan areas are rational and their risk preferences are neutral. In the process of cooperation, information is symmetrical and each pursues profit maximization. The TPL service provider's freshness and epidemic prevention efforts can be improved and can be measured.

Assumption 2. The market demand for FAPs in metropolis is mainly affected by price, freshness and safety. Assume that the market demand function is $D=a-b p_{r}+\left(k_{1}+k_{2}\right) \theta . a, b$, and $k$ are all greater than 0 and constant. $a$ represents the initial demand for FAPs in metropolitan areas in the context of COVID-19. $b, k_{1}$ and $k_{2}$ represent the sensitivity coefficient of the market demand of FAPs in metropolis to retail price, freshness and safety. The degree $\theta=\left(\theta_{01}+\theta_{02}\right)\left(e_{1}+e_{2}\right)$ of preservation of FAPs indicates the quality level of FAPs, which is affected by the level of preservation efforts and the level of epidemic prevention efforts. $\theta_{01}$ and $\theta_{02}$ are the initial freshness and epidemic prevention degree of FAPs. $e_{1}$ and $e_{2}$ 's efforts in preservation and epidemic prevention for TPL service providers. Let $\beta=\left(k_{1}+k_{2}\right)\left(\theta_{01}+\theta_{02}\right)$ represents the sensitivity coefficient of the demand for FAPs in metropolis to the level of preservation efforts and epidemic prevention efforts. Therefore, in the context of COVID-19 epidemic, the market demand function of FAPs in metropolitan areas is $D=a-b p_{r}+\beta\left(e_{1}+e_{2}\right)$.

Assumption 3. In the context of COVID-19, the relationship between the cost of FAPs in metropolitan areas and the level of preservation efforts and the level of epidemic prevention efforts is $C=\frac{1+\sigma}{2} \lambda\left(e_{1}+e_{2}\right)^{2}$. It shows that the improvement of TPL's quality assurance effort level can lead to the increase of quality assurance cost, and the quality assurance cost shows a marginal increasing trend.

Assumption 4. The parameter satisfies the following relation $p_{r}>p_{w}+p_{l 1}+p_{l 2}$, indicating that the retail price of retailer's unit FAPs is greater than the sum of supplier's unit wholesale price of FAPs and TPL service provider's guaranteed delivery price. $p_{w}>c_{w}+t L_{1}+t L_{2}$ means that when the TPL service provider does not provide quality assurance services, the wholesale price per unit of FAPs of the supplier is greater than the sum of the cost per unit of FAPs and the cost of quantity loss. 
$a-b\left(c_{w}+t L_{1}+t L_{2}+p_{l 1}+p_{l 2}\right)>0$ indicates that in the context of COVID-19, when TPL providers do not provide quality assurance services, the market demand for FAPs in metropolitan areas is positively correlated with the profits of supply chain members at all levels.

\section{Quality assurance strategy of FAPs under the guidance of suppliers}

Under the background of new crown pneumonia, suppliers play a leading role in the 3 level supply chain structure of FAPs with good quality in metropolis. When the supplier of FAPs is in the leading position of supply guarantee, first of all, the supplier of FAPs formulates the optimal unit wholesale price of FAPs $p_{w}$. TPL service providers then make decisions to maximize their own profits. TPL service provider selects level $e_{1}$ of fresh keeping efforts and level $e_{2}$ of epidemic prevention efforts, and reports to retailers the fresh keeping price $p_{l 1}$ and epidemic prevention price $p_{l 2}$. Finally, according to the wholesale price of FAPs given by the supplier and the quality assurance level given by the TPL service provider, the best retail price $p_{r}$ of FAPs is finally determined by the FAPs retailers based on their own profit maximization conditions.

According to the above game process, the Stackelberg game model of supplier led supply guarantee can be constructed under the situation that the level of quality assurance efforts affects the market demand. In the context of the outbreak of new crown pneumonia, the profit function of suppliers in the 3 level supply chain structure of FAPs with good quality in metropolis can be expressed as follows

$$
\pi_{w}=\left(p_{w}-c_{w}\right)\left(a-b p_{r}+\beta\left(e_{1}+e_{2}\right)\right)-\left(t L_{1}+t L_{2}\right)\left(1-e_{1}-e_{2}\right)\left(a-b p_{r}+\beta\left(e_{1}+e_{2}\right)\right)
$$

In formula (1), $\left(p_{w}-c_{w}\right)\left(a-b p_{r}+\beta\left(e_{1}+e_{2}\right)\right)$ represents the income of FAPs suppliers. $\left(t L_{1}+t L_{2}\right)\left(1-e_{1}-e_{2}\right)\left(a-b p_{r}+\beta\left(e_{1}+e_{2}\right)\right)$ represents the consumption cost and epidemic prevention cost paid by the suppliers of FAPs to meet the demand of FAPs. The profit function of TPL service providers can be expressed as follows

$$
\pi_{l}=\left(p_{l 1}+p_{l 2}-c_{l}\right)\left(a-b p_{r}+\beta\left(e_{1}+e_{2}\right)\right)-\frac{1+\sigma}{2} \lambda\left(e_{1}+e_{2}\right)^{2}
$$

In formula (2), $\left(p_{l 1}+p_{l 2}-c_{l}\right)\left(a-b p_{r}+\beta\left(e_{1}+e_{2}\right)\right)$ represents the income obtained by the TPL service provider from the transportation of FAPs. $\frac{1+\sigma}{2} \lambda\left(e_{1}+e_{2}\right)^{2}$ represents the fresh keeping cost and epidemic prevention cost of FAPs invested by TPL service provider. The profit function of fresh produce retailers can be expressed as follows

$$
\pi_{r}=\left(p_{r}-p_{w}-p_{l 1}-p_{l 2}\right)\left(a-b p_{r}+\beta\left(e_{1}+e_{2}\right)\right)
$$

According to the above game model, the reverse order method is used to solve the above profit function. For the convenience of solution, let $p_{r}=p_{w}+\delta$, where $\delta$ is the increased price of FAPs retailers. Then the profit function of fresh produce retailers can be expressed as follows

$$
\pi_{r}=\left(\delta-p_{l 1}-p_{l 2}\right)\left[a-b\left(p_{w}+\delta\right)+\beta\left(e_{1}+e_{2}\right)\right]
$$

For the first partial derivative of formula (4) with respect to $\delta$, there is $\frac{\partial \pi_{r}}{\partial \delta}=a-b\left(p_{w}+\delta\right)+\beta\left(e_{1}+e_{2}\right)+\left(\delta-p_{l 1}-p_{l 2}\right)(-b)$. Since $\frac{\partial^{2} \pi_{r}}{\partial \delta^{2}}=-2 b<0, \pi_{r}$ is a convex function of $\delta$. For FAPs retailers, there is only one optimal retail price to maximize the profit. If $\frac{\partial \pi_{r}}{\partial \delta}=0$, the relationship between the price $\delta_{l}$ increased by 
the best FAPs retailer and the wholesale price $p_{w}$, the level of preservation efforts $e_{1}$ and the level of epidemic prevention efforts $e_{2}$ can be expressed as follows

$$
\delta_{l}=\frac{a-b p_{w}+\beta\left(e_{1}+e_{2}\right)+\left(p_{l 1}+p_{l 2}\right) b}{2 b}
$$

$$
\pi_{l}=\left(p_{l 1}+p_{l 2}-c_{l}\right)\left[a-b \frac{a+b p_{w}+\beta\left(e_{1}+e_{2}\right)+\left(p_{l 1}+p_{l 2}\right) b}{2 b}+\beta\left(e_{1}+e_{2}\right)\right]-\frac{1+\sigma}{2} \lambda\left(e_{1}+e_{2}\right)^{2}(7)
$$

\section{retailer increases the price, the profit function of} retailer increases the price, the profit function of TPL service provider can be expressed as follows

For the first partial derivatives of formula (7) for $e_{1}$ and $e_{2}$, there is $\frac{\partial \pi_{l}}{\partial\left(e_{1}+e_{2}\right)}=\frac{\beta}{2}\left(p_{l 1}+p_{l 2}-c_{l}\right)-(1+\sigma) \lambda\left(e_{1}+e_{2}\right)$.

Since $\frac{\partial^{2} \pi_{l}}{\partial\left(e_{1}+e_{2}\right)^{2}}=-(1+\sigma) \lambda<0, \pi_{l}$ is a convex function of $e_{1}$ and $e_{2}$. It can be seen that for TPL service providers, there is only one optimal level of preservation efforts and epidemic prevention efforts to maximize profits. If $\frac{\partial \pi_{l}}{\partial\left(e_{1}+e_{2}\right)}=0$, the level of FAPs preservation and epidemic prevention efforts paid by TPL under the guidance of FAPs suppliers can be expressed as follows

$$
\left(e_{1}+e_{2}\right)_{1}^{*}=\frac{\beta\left(p_{l 1}+p_{l 2}-c_{l}\right)}{2(1+\sigma) \lambda}
$$

When $p_{r}=p_{w}+\delta$, the profit function of fresh produce suppliers can be expressed as follows

$$
\pi_{w}=\left(p_{w}-c_{w}\right)\left[a-b\left(p_{w}+\delta\right)+\beta\left(e_{1}+e_{2}\right)\right]-\left(t L_{1}+t L_{2}\right)\left(1-e_{1}-e_{2}\right)\left[a-b\left(p_{w}+\delta\right)+\beta\left(e_{1}+e_{2}\right)\right]
$$

Substituting formula (5) and formula (8) into (9), the profit function of the FAPs supplier is $\pi_{w}\left(p_{w}\right)$ under the conditions of the increased price of the best FAPs retailer, the best fresh keeping effort level and the epidemic prevention effort level. The first partial derivative of $p_{w}$ is solved with $\frac{\partial \pi_{w}}{\partial p_{w}}=\frac{2 \lambda(1+\sigma)\left(a-b p_{w}-b\left(p_{l 1}+p_{l 2}\right)\right)+\beta^{2}\left(\left(p_{l 1}+p_{l 2}\right)-c_{l}\right)}{4 \lambda(1+\sigma)}$

$-\frac{b}{2}\left[p_{w}-c_{w}-\frac{\left(t L_{1}+t L_{2}\right)\left(2 \lambda(1+\sigma)-\beta\left(p_{l 1}+p_{l 2}\right)+\beta c_{l}\right)}{2 \lambda(1+\sigma)}\right]$

Since $\frac{\partial^{2} \pi_{w}}{\partial p_{w}^{2}}=b-0, \pi_{w}$ is a convex function of $p_{w}$. For FAPs suppliers, there is a unique optimal wholesale price to maximize their profits. If $\frac{\partial \pi_{w}}{\partial p_{w}}=0$, under novel coronavirus pneumonia background, the optimal wholesale price of FAPs suppliers under the dominant supplier of FAPs can be expressed as follows 


$$
\left(p_{w}\right)_{1}^{*}=\frac{2 \lambda(1+\sigma)\left(a-b\left(p_{l 1}+p_{l 2}\right)+b c_{w}+b\left(t L_{1}+t L_{2}\right)\right)+\left(p_{l 1}+p_{l 2}-c_{l}\right)\left(\beta^{2}-b\left(t L_{1}+t L_{2}\right) \beta\right)}{4 \lambda b(1+\sigma)}
$$

The results of equation (5), equation (8) and equation (10) are substituted into $p_{r}=p_{w}+\delta$. In the case of the optimal fresh agricultural product retailer's increased price, optimal fresh keeping effort level, epidemic prevention effort level and optimal wholesale price, the optimal retail price of the retailer under the fresh agricultural product supplier led supply guarantee can be expressed as follows

$$
\left(p_{r}\right)_{1}^{*}=\frac{2 \lambda(1+\sigma)\left(3 a+b\left(p_{l 1}+p_{l 2}\right)+b c_{l}+b\left(t L_{1}+t L_{2}\right)\right)+\left(p_{l 1}+p_{l 2}-c_{l}\right)\left(3 \beta^{2}-b\left(t L_{1}+t L_{2}\right) \beta\right)}{8 \lambda b(1+\sigma)}
$$

Novel coronavirus pneumonia ( $D=a-b p_{r}+\beta\left(e_{1}+e_{2}\right)$ ) formula (8) and formula (11) were applied to the market demand function of FAPs in the background of the new crown pneumonia epidemic. In the case of TPL's optimal quality (preservation and epidemic prevention) effort level and retailer's optimal retail price, the optimal order quantity of FAPs retailer (Metropolitan FAPs demand) under supplier led supply guarantee can be expressed as follows

$$
D_{1}^{*}=\frac{2 \lambda(1+\sigma)\left(a-b\left(p_{l 1}+p_{l 2}\right)-b c_{l}-b\left(t L_{1}+t L_{2}\right)\right)+\left(p_{l 1}+p_{l 2}-c_{l}\right)\left(\beta^{2}+b \beta\left(t L_{1}+t L_{2}\right)\right)}{8 \lambda(1+\sigma)}
$$

The results of equation (8), equation (10) and equation (11) are substituted into equation (1), equation (2) and equation (3) respectively. Under the background of novel coronavirus pneumonia, the optimal profit of three suppliers $\pi_{w_{1}}$, TPL service providers $\pi_{l_{1}}$ and retailers $\pi_{r_{1}}$ of the dominant suppliers in the metropolis FAPs suppliers can be expressed as follows

$$
\begin{gathered}
\pi_{{ }_{w_{1}}}^{*}=\frac{\left[2 \lambda a(1+\sigma)-2 \lambda b(1+\sigma)\left(c_{l}+p_{l 1}+p_{l 2}+t L_{1}+t L_{2}\right)+\left(\beta^{2}+b \beta\left(t L_{1}+t L_{2}\right)\right)\left(p_{l 1}+p_{l 2}-c_{l}\right)\right]^{2}}{32 b \lambda^{2}(1+\sigma)^{2}} \\
\pi_{l_{1}}^{*}=\frac{\left(p_{l 1}+p_{l 2}-c_{l}\right)\left[2 \lambda a(1+\sigma)-2 \lambda b(1+\sigma)\left(c_{l}+p_{l 1}+p_{l 2}+t L_{1}+t L_{2}\right)+b \beta\left(t L_{1}+t L_{2}\right)\left(p_{l 1}+p_{l 2}-c_{l}\right)\right]}{8 \lambda(1+\sigma)}(14) \\
\pi_{r_{1}}^{*}=\frac{\left[2 \lambda a(1+\sigma)-2 \lambda b(1+\sigma)\left(c_{l}+p_{l 1}+p_{l 2}+t L_{1}+t L_{2}\right)+\left(\beta^{2}+b \beta\left(t L_{1}+t L_{2}\right)\right)\left(p_{l 1}+p_{l 2}-c_{l}\right)\right]^{2}}{64 b \lambda^{2}(1+\sigma)^{2}}
\end{gathered}
$$

It can be seen from the above that equations (13), (14) and (15) respectively represent the optimal profits of suppliers, TPL service providers and retailers under the conditions of optimal retailer price increase, optimal preservation effort level, optimal epidemic prevention effort level and optimal wholesale price of suppliers.

\section{Quality assurance strategy of FAPs under the guidance of retailers}

In the context of COVID-19 epidemic, retailers are leading the supply of FAPs in a three-tier supply chain structure for quality assurance in metropolitan areas. When FAPs retailers are in the leading position of supply guarantee, first of all, metropolitan FAPs retailers decide the appropriate retail price $p_{r}$. The TPL service provider then makes decisions based on its profit maximization. The TPL service provider determines the optimal freshness preservation effort level $e_{1}$ and epidemic prevention effort level $e_{2}$, and reports to the retailer the FAPs freshness service price $p_{l 1}$ and epidemic prevention service value $p_{l 2}$. Finally, suppliers of FAPs combine their profit maximization conditions according to the retail price given by retailers and the quality 
assurance effort level given by TPL. On this basis, FAPs suppliers decide the optimal wholesale price $p_{w}$ of FAPs.

According to the above game process, a Stackelberg game model of retailer-led guarantee can be built in the case that the level of preservation effort affects the market demand. The reverse order method is used to solve the Stackelberg game model. The first partial derivative of Equation (9) with respect to $p_{w}$ is solved, and the results can be expressed as follows

$$
\frac{\partial \pi_{w}}{\partial p_{w}}=a-b\left(p_{w}+\delta\right)+\beta\left(e_{1}+e_{2}\right)+\left[p_{w}-c_{l}-\left(t L_{1}+t L_{2}\right)\left(1-\left(e_{1}+e_{2}\right)\right)\right](-b)
$$

Since $\frac{\partial^{2} \pi_{w}}{\partial p_{w}^{2}}=-2 b<0, \pi_{w}$ is A convex function of $p_{w}$. Suppliers of FAPs have a single optimal wholesale price to maximize their profits. With $\frac{\partial \pi_{w}}{\partial p_{w}}=0$, the relationship between the optimal wholesale price $p_{w}$ and the retailer's mark-up of FAPs as well as the freshness preservation effort level $e_{1}$ and the epidemic prevention effort level $e_{2}$ can be expressed as follows

$$
\left(p_{w}\right)_{2}=\frac{a-b \delta+\beta\left(e_{1}+e_{2}\right)+b c_{l}+b\left(t L_{1}+t L_{2}\right)\left(1-\left(e_{1}+e_{2}\right)\right)}{2 b}
$$

Equation (17) is substituted into Equation (6) to obtain the profit function of TPL service providers under the optimal wholesale price. The profit function of TPL service providers can be expressed as follows

$$
\pi_{l}=\frac{1}{2}\left(p_{l 1}+p_{l 2}-c_{l}\right)\left[a-b \delta-b c_{l}-b\left(t L_{1}+t L_{2}\right)+\left(\beta+b\left(t L_{1}+t L_{2}\right)\right)\left(e_{1}+e_{2}\right)\right]-\frac{1+\sigma}{2} \lambda\left(e_{1}+e_{2}\right)^{2}
$$

To solve the first partial derivative of equation (18) with respect to $e_{1}$ and $e_{2}$, there exists $\frac{\partial \pi_{l}}{\partial\left(e_{1}+e_{2}\right)}=\frac{1}{2}\left(p_{l 1}+p_{l 2}-c_{l}\right)\left(\beta+b\left(t L_{1}+t L_{2}\right)\right)-\lambda(1+\sigma)\left(e_{1}+e_{2}\right)$. Since $\frac{\partial^{2} \pi_{l}}{\partial\left(e_{1}+e_{2}\right)^{2}}=-(1+\sigma) \lambda<0, \pi_{l}$ is a convex function of $e_{1}$ and $e_{2}$. TPL service providers of FAPs have a unique level of quality assurance efforts to maximize their profits. If $\frac{\partial \pi_{l}}{\partial\left(e_{1}+e_{2}\right)}=0$, the optimal quality assurance effort level of TPL under the retailer-led guarantee of FAPs can be expressed as follows

$$
\left(e_{1}+e_{2}\right)_{2}^{*}=\frac{\left(\beta+b\left(t L_{1}+t L_{2}\right)\right)\left(p_{l 1}+p_{l 2}-c_{l}\right)}{2 \lambda(1+\sigma)}
$$

Equation (17) and Equation (19) are substituted into Equation (4) to obtain the profit function $\pi_{r}(\delta)$ of FAPs retailers under the condition of the optimal wholesale price and the optimal quality assurance effort level of TPL. The first partial derivative with respect to $\delta$ is solved, and there is $\frac{\partial \pi_{r}}{\partial \delta}=\frac{a-b \delta-b c_{l}-b\left(t L_{1}+t L_{2}\right)}{2}-\frac{b}{2}\left(\delta-p_{l 1}-p_{l 2}\right)+\frac{\left(p_{l 1}+p_{l 2}-c_{l}\right)\left(\beta+b\left(t L_{1}+t L_{2}\right)\right)^{2}}{4 \lambda(1+\sigma)}$. 
Since $\frac{\partial^{2} \pi_{r}}{\partial \delta^{2}}=-b<0, \pi_{r}$ is a convex function of $\delta$. Fresh produce retailers have

The solution results of Equations (19) and (20) are substituted into Equation (17). In the case of TPL's optimal quality effort level and optimal retailer markup, the supplier's optimal wholesale price when fresh agricultural product retailer dominates the warranty can be expressed as follows

$$
\delta_{2}=\frac{2 \lambda(1+\sigma)\left(a-b c_{l}-b\left(t L_{1}+t L_{2}\right)+b\left(p_{l 1}+p_{l 2}\right)\right)+\left(\beta+b\left(t L_{1}+t L_{2}\right)\right)^{2}\left(p_{l 1}+p_{l 2}-c_{l}\right)}{2 \lambda b(1+\sigma)}
$$

a single optimal retail price to maximize their profits. Let $\frac{\partial \pi_{r}}{\partial \delta}=0$ to get the optimal fresh agricultural product retailer price increase under the leading guarantee of fresh agricultural product can be expressed as follows

$$
\left(p_{w}\right)_{2}^{*}=\frac{2 \lambda(1+\sigma)\left(a-b\left(p_{l 1}+p_{l 2}\right)+3 b c_{l}+3 b\left(t L_{1}+t L_{2}\right)\right)+\left(p_{l 1}+p_{l 2}-c_{l}\right)\left(\beta^{2}-3 b^{2}\left(L_{1}+L_{2}\right)^{2} t^{2}-2 \beta b\left(t L_{1}+t L_{2}\right)\right)}{8 \lambda b(1+\sigma)}
$$

Equations (20) and (21) are substituted into $p_{r}=p_{w}+\delta$. In the case of optimal price increase and optimal wholesale price, the retailer's optimal retail price can be expressed as follows when the retailer of FAPs is leading the guarantee of supply

$$
\left(p_{r}\right)_{2}^{*}=\frac{2 \lambda(1+\sigma)\left(3 a+b c_{l}+b\left(t L_{1}+t L_{2}\right)+b\left(p_{l 1}+p_{l 2}\right)\right)+\left(p_{l 1}+p_{l 2}-c_{l}\right)\left(3 \beta^{2}+2 \beta b\left(t L_{1}+t L_{2}\right)-b^{2} t^{2}\left(L_{1}+L_{2}\right)^{2}\right)}{8 \lambda b(1+\sigma)}
$$

Equation (19) and Equation (22) were substituted into the market demand function $D=a-b p_{r}+\beta\left(e_{1}+e_{2}\right)$ for FAPs in metropolitan areas in the context of COVID-19 outbreak. In the case of the TPL's optimal quality (fresh and epidemic prevention) effort level and the retailer's optimal retail price, the retailer's optimal order quantity (metropolitan fresh produce demand) for fresh produce under the retailer's leading guarantee can be expressed as follows

$$
D_{2}^{*}=\frac{2 \lambda(1+\sigma)\left(a-b\left(p_{l 1}+p_{l 2}\right)-b c_{l}-b\left(t L_{1}+t L_{2}\right)\right)+\left(p_{l 1}+p_{l 2}-c_{l}\right)\left(\beta+b\left(t L_{1}+t L_{2}\right)\right)^{2}}{8 \lambda(1+\sigma)}
$$

Equations (19), (21) and (22) are substituted into equations (1), (2) and (3) respectively. The optimal profit of the supplier $\pi_{w_{2}}$, TPL service provider $\pi_{l_{2}}$ and retailer $\pi_{r_{2}}$ under the dominant guarantee status of the retailer can be expressed as follows

$$
\begin{array}{r}
\pi_{w_{2}}^{*}=\frac{\left[2 \lambda(1+\sigma)\left(a-b c_{l}-b\left(t L_{1}+t L_{2}\right)-b\left(p_{l 1}+p_{l 2}\right)\right)+\left(\beta+b\left(t L_{1}+t L_{2}\right)\right)^{2}\left(p_{l 1}+p_{l 2}-c_{l}\right)\right]^{2}}{64 b \lambda^{2}(1+\sigma)^{2}}(24) \\
\pi_{l_{2}}^{*}=\frac{\left(p_{l 1}+p_{l 2}-c_{l}\right)\left(a-b c_{l}-b\left(t L_{1}+t L_{2}\right)-b\left(p_{l 1}+p_{l 2}\right)\right)}{4}(25)
\end{array}
$$

$$
\pi_{r_{2}}^{*}=\frac{\left[2 \lambda(1+\sigma)\left(a-b c_{l}-b\left(t L_{1}+t L_{2}\right)-b\left(p_{l 1}+p_{l 2}\right)\right)+\left(\beta+b\left(t L_{1}+t L_{2}\right)\right)^{2}\left(p_{l 1}+p_{l 2}-c_{l}\right)\right]^{2}}{32 b \lambda^{2}(1+\sigma)^{2}}
$$

As can be seen from the above, equations (24), (25) and (26) respectively represent the optimal profit of suppliers, TPL service providers and retailers when the retailer takes the lead in the guarantee of supply under the conditions of the optimal retailer 
price increase, the optimal freshness preservation effort level, the optimal epidemic prevention effort level and the optimal wholesale price of suppliers.

\section{Comparative analysis of control strategies for FAPs}

In the context of the COVID-19 epidemic, the quality of FAPs in metropolitan areas is one of the necessary conditions to meet the needs of residents. The quality assurance strategy of FAPs is compared and analyzed, that is, the best quality assurance strategy of FAPs under the supplier leading guarantee and the retailer leading guarantee. These strategies include the following factors: TPL service provider's freshness preservation effort level, supplier's wholesale price, retailer's retail price, and metropolitan fresh produce demand.

Proposition 1. Equation (8) and Equation (19) are compared by $p_{l 1}+p_{l 2}>c_{l}$. The optimal quality assurance effort level (freshness effort level and epidemic prevention effort level) of TPL service providers under the two game models satisfies $\left(e_{1}+e_{2}\right)_{1}^{*} \leq\left(e_{1}+e_{2}\right)_{2}^{*}$.

Proposition 1 shows that TPL service providers have a higher level of epidemic prevention efforts and preservation efforts for FAPs when FAPs retailers are in the leading position of guarantee and supply compared with FAPs suppliers. Compared with FAPs suppliers and TPL service providers, FAPs retailers have more decision-making power of FAPs quality. TPL service providers can only cooperate by putting a higher level of prevention efforts and preservation efforts than fresh produce retailers. And TPL service providers can meet consumers' high requirements for the quality of FAPs. At the same time, this proposition indicates that in the context of COVID-19 epidemic, the sensitivity of the market demand of FAPs in metropolitan areas to the level of epidemic prevention efforts and preservation efforts will, to a certain extent, offset the impact of the dominant position of supply and demand. When FAPs suppliers are in the leading position of guarantee and supply, the relative size of epidemic prevention efforts and preservation efforts depends on the sensitivity of FAPs market demand to TPL preservation efforts in metropolis.

Proposition 2. For the optimal wholesale price of FAPs suppliers, the wholesale price under the supplier-led guarantee is higher than the wholesale price under the retailer-led guarantee, namely, $\left(p_{w}\right)_{2}^{*}<\left(p_{w}\right)_{1}^{*}$.

Proof. From hypothesis $p_{l 1}+p_{l 2}>c_{l}$ and $a-b\left(c_{l}+t\left(L_{1}+L_{2}\right)+p_{l 1}+p_{l 2}\right)>0$, it can be obtained that

$$
\begin{aligned}
& \left(p_{w}\right)_{1}^{*}-\left(p_{w}\right)_{2}^{*}=\frac{2 \lambda(1+\sigma)\left(a-b\left(p_{l 1}+p_{l 2}\right)+b c_{w}+b\left(t L_{1}+t L_{2}\right)\right)+\left(p_{l 1}+p_{l 2}-c_{l}\right)\left(\beta^{2}-b\left(t L_{1}+t L_{2}\right) \beta\right)}{4 \lambda b(1+\sigma)} \\
& -\frac{2 \lambda(1+\sigma)\left(a-b\left(p_{l 1}+p_{l 2}\right)+3 b c_{l}+3 b\left(t L_{1}+t L_{2}\right)\right)+\left(p_{l 1}+p_{l 2}-c_{l}\right)\left(\beta^{2}-3 b^{2}\left(L_{1}+L_{2}\right)^{2} t^{2}-2 \beta b\left(t L_{1}+t L_{2}\right)\right)}{8 \lambda b(1+\sigma)}>0
\end{aligned}
$$

So $\left(p_{w}\right)_{2}^{*}<\left(p_{w}\right)_{1}^{*}$.

Proposition 2 shows that the wholesale price of FAPs under the leading guarantee is higher than the wholesale price of FAPs under the leading guarantee. When FAPs suppliers have the dominant guarantee advantage, FAPs suppliers have stronger bargaining power than retailers. Profits for suppliers of fresh produce increase with higher pricing.

Proposition 3. For the retailer's optimal retail price under three game models, if $\frac{b\left(t L_{1}+t L_{2}\right)}{3} \leq \beta$, then $\left(p_{r}\right)_{1}^{*}<\left(p_{r}\right)_{2}^{*}$. If $\beta<\frac{b\left(t L_{1}+t L_{2}\right)}{3}$, then $\left(p_{r}\right)_{2}^{*}<\left(p_{r}\right)_{1}^{*}$. 
Proof. By hypothesis $p_{l 1}+p_{l 2}>c_{l}$, so

$\left(p_{r}\right)_{1}^{*}-\left(p_{r}\right)_{2}^{*}=\frac{\left(p_{l}-c_{l}\right)\left(b^{2} r^{2} t^{2}-3 \beta b r t\right)}{8 \lambda b}=\frac{b r t\left(p_{l}-c_{l}\right)(b r t-3 \beta)}{16 \lambda b}$

If $\frac{b\left(t L_{1}+t L_{2}\right)}{3} \leq \beta$, then $\left(p_{r}\right)_{1}^{*}<\left(p_{r}\right)_{2}^{*}$. If $\beta<\frac{b\left(t L_{1}+t L_{2}\right)}{3}$, then

$\left(p_{r}\right)_{2}^{*}<\left(p_{r}\right)_{1}^{*}$

Proposition 3 shows that when $\frac{b\left(t L_{1}+t L_{2}\right)}{3} \leq \beta$, retailers of FAPs tend to set a higher retail price when they are in the leading guarantee position, compared with suppliers of FAPs who lead the guarantee. When $\beta<\frac{b\left(t L_{1}+t L_{2}\right)}{3}$, retailers of FAPs tend to set a higher retail price when the supplier is in the leading guarantee position, compared with FAPs retailers in the leading guarantee position. According to the retailer response expression obtained above, the optimal retail price is related to the supplier's wholesale price and the TPL's quality assurance effort level. If the level of quality assurance efforts remains consistent, the comparative analysis of the wholesale price (proposition 2) shows that $\left(p_{w}\right)_{2}^{*}<\left(p_{w}\right)_{1}^{*}$ and $\left(p_{r}\right)_{2}^{*}<\left(p_{r}\right)_{1}^{*}$. According to proposition 1 , if the condition of $\frac{b\left(t L_{1}+t L_{2}\right)}{3} \leq \beta$ is satisfied, then $\left(e_{1}+e_{2}\right)_{1}^{*} \leq\left(e_{1}+e_{2}\right)_{2}^{*}$, which is consistent with the conclusion of this proposition, $\left(p_{r}\right)_{1}^{*}<\left(p_{r}\right)_{2}^{*}$. It can be seen that, compared with the wholesale price of FAPs, the level of preservation efforts and epidemic prevention efforts will have a greater impact on the retail price of FAPs in metropolis.

Proposition 4. In the context of COVID-19 epidemic, the optimal order quantity of metropolitan FAPs system is $D_{1}^{*}<D_{2}^{*}$ based on hypothesis $p_{l 1}+p_{l 2}>c_{l}$ and $a-b\left(c_{l}+t\left(L_{1}+L_{2}\right)+p_{l 1}+p_{l 2}\right)>0$.

The conclusion of proposition 4 is similar to that of propositions 1 and 3 . According to the demand function, the market demand of FAPs in metropolis is related to the retail price, the level of fresh-keeping efforts and the level of epidemic prevention efforts. The retail price of FAPs in metropolis has the following relationship $\left(p_{r}\right)_{1}^{*}<\left(p_{r}\right)_{2}^{*}$, the level of preservation efforts and epidemic prevention efforts meet the level of $\left(e_{1}+e_{2}\right)_{1}^{*} \leq\left(e_{1}+e_{2}\right)_{2}^{*}$. The market demand of FAPs in metropolis is negatively correlated with the retail price and positively correlated with the quality assurance effort level. So the relationship between the level of preservation effort is consistent with the conclusion of this thesis. In general, the optimal order quantity of FAPs in metropolis is related to the sensitivity coefficient of preservation effort level and epidemic prevention effort level.

Proposition 5. When fresh produce suppliers are in the leading position of guarantee, the profit of fresh produce suppliers is twice that of retailers. When fresh produce retailers are in the leading position of guarantee, fresh produce retailers' profit is twice that of their suppliers. There are $\pi_{w 1}=2 \pi_{r 1}$ and $2 \pi_{w 2}=\pi_{r 2}$.

Proof. By assuming $p_{l 1}+p_{l 2}>c_{l}$ and $a-b\left(c_{l}+t\left(L_{1}+L_{2}\right)+p_{l 1}+p_{l 2}\right)>0$ and comparing equations (13) and (15), it can be known that $\pi_{w 1}=2 \pi_{r 1}$. By comparing equation (24) with Equation (26), it can be known that $2 \pi_{w 2}=\pi_{r 2}$. 
Proposition 5 shows that the profit ratio between FAPs suppliers and retailers is 2:1 under the supplier - led guarantee. Under the retailer-led guarantee, the profit ratio of FAPs suppliers and retailers is 1:2. When the guarantee subject is in the dominant guarantee position, it has stronger control ability and decision-making ability compared with other members, so that its own profit is greater than that of other members.

Proposition 6. By assuming $p_{l 1}+p_{l 2}>c_{l}$, equations (15) and (26) are compared. Compared with the leading guarantee and supply of FAPs, the profit of FAPs retailers is larger when the retailers are in the leading guarantee and supply position, that is, $\pi_{r 1}<\pi_{r 2}$.

The conclusion of proposition 6 is consistent with that of Proposition 1, 3 and 4, indicating that there is a certain relationship between the relative size of retailers' profits and the sensitivity of their quality assurance efforts. If the sensitivity coefficient of the quality assurance effort level is low enough, the quality assurance effort level and market demand are greater under the retailer-led warranty than under the supplier led warranty. When $\beta>b r t$, compared with the supplier-led guarantee, the quality assurance effort level, market demand and retail price are all greater under the retailer-led guarantee. As increased demand leads to higher revenue, retail prices are higher, leading to higher margins. The profit of retailers of FAPs is affected by the sensitivity coefficient of preservation efforts, epidemic prevention efforts and the dominant guarantee status.

Proposition 7. In the context of COVID-19 epidemic, with the increase of preference of FAPs consumers to epidemic prevention efforts and preservation efforts in metropolitan areas, the profits of TPL service providers led by FAPs retailers remain unchanged. Under the leading guarantee of FAPs suppliers, the profit level of the guarantee members will be increased, that is, $\frac{\partial \pi_{w}^{*}}{\partial \beta}>0, \frac{\partial \pi_{l}^{*}}{\partial \beta}>0$ and $\frac{\partial \pi_{r}^{*}}{\partial \beta}>0$.

Proof. Under the leading guarantee of FAPs suppliers, the derivative results of the optimal profits of members at all levels with respect to the sensitivity coefficient of preservation efforts can be expressed as follows

$\frac{\partial \pi_{{ }_{11}}^{*}}{\partial \beta}=\frac{2\left[2 \lambda a(1+\sigma)-2 \lambda b(1+\sigma)\left(c_{l}+p_{l 1}+p_{l 2}+t L_{1}+t L_{2}\right)+\left(\beta^{2}+b\left(t L_{1}+t L_{2}\right) \beta\right)\left(p_{l 1}+p_{l 2}-c_{l}\right)\right]\left(p_{l 1}+p_{l 2}-c_{l}\right)\left(2 \beta+b\left(t L_{1}+t L_{2}\right)\right)}{32 b \lambda^{2}(1+\sigma)^{2}}$

$$
\frac{\partial \pi_{{ }_{i_{1}}}^{*}=\frac{2\left[2 \lambda a(1+\sigma)-2 \lambda b(1+\sigma)\left(c_{l}+p_{l 1}+p_{l 2}+t L_{1}+t L_{2}\right)+\left(\beta^{2}+b\left(t L_{1}+t L_{2}\right) \beta\right)\left(p_{l 1}+p_{l 2}-c_{l}\right)\right]\left(p_{l 1}+p_{l 2}-c_{l}\right)\left(2 \beta+b\left(t L_{1}+t L_{2}\right)\right)}{\partial \beta}}{64 b \lambda^{2}(1+\sigma)^{2}}
$$

By assuming that $p_{l 1}+p_{l 2}>c_{l}$ and $a-b\left(c_{l}+t\left(L_{1}+L_{2}\right)+p_{l 1}+p_{l 2}\right)>0$, then $\frac{\partial \pi^{*}{ }_{w_{1}}}{\partial \beta}>0$ and $\frac{\partial \pi_{{ }_{1}}^{*}}{\partial \beta}>0$ can be determined.

In the case of retailer-led guarantee, the derivative expression of the sensitivity coefficient of quality assurance effort was used to judge. Similarly, the proposition is as follows

$$
\frac{\partial \pi_{w_{2}}^{*}}{\partial \beta}=\frac{2\left[2 \lambda(1+\sigma)\left(a-b c_{l}-b\left(t L_{1}+t L_{2}\right)-b\left(p_{l 1}+p_{l 2}\right)\right)+\left(\beta+b\left(t L_{1}+t L_{2}\right)\right)^{2}\left(p_{l 1}+p_{l 2}-c_{l}\right)\right] 2\left(\beta+b\left(t L_{1}+t L_{2}\right)\right)\left(p_{l 1}+p_{l 2}-c_{l}\right)}{64 b \lambda^{2}(1+\sigma)^{2}}>0
$$




$$
\frac{\partial \pi_{r_{2}}^{*}}{\partial \beta}=\frac{2\left[2 \lambda(1+\sigma)\left(a-b c_{s}-b\left(t L_{1}+t L_{2}\right)-b\left(p_{l 1}+p_{l 2}\right)\right)+\left(\beta+b\left(t L_{1}+t L_{2}\right) \beta\right)^{2}\left(p_{l 1}+p_{l 2}-c_{l}\right)\right] 2\left(\beta+b\left(t L_{1}+t L_{2}\right)\right)\left(p_{l 1}+p_{l 2}-c_{l}\right)}{32 b \lambda^{2}(1+\sigma)^{2}}>0
$$

Question 7 shows that when FAPs retailers dominate the supply guarantee, the profit of TPL service provider has nothing to do with the sensitivity coefficient of the quality assurance effort level. There is a positive correlation between the sensitivity coefficient of quality assurance effort and the optimal profit of the members of the supply chain under the game situation of FAPs supplier leading the guarantee and supply. The profits of TPL service providers under the leading guarantee of FAPs retailers in metropolis remained unchanged. With the increase of consumers' preference for epidemic prevention efforts and preservation efforts. In the supply chain structure where suppliers and retailers are respectively in the leading position of supply guarantee, the profit of supply guarantee members will gradually increase.

\section{Conclusion and future research direction}

In the context of COVID-19, ensuring the effective supply of FAPs in metropolises is the key to realizing the joint prevention and control mechanism in metropolises. The rapid spread of COVID-19 has made a major public health emergency the biggest uncertain risk currently restricting the orderly operation of metropolitan areas and threatening the effective supply of agricultural products. The COVID-19 epidemic has been going on for nearly a year, and as the virus mutates, the timing of the end is becoming more uncertain. The epidemic has had a major impact on the food and food life in the metropolis, and FAPs are also inevitably affected. The effective supply of FAPs during the epidemic prevention and control period has become an important part of the response to the epidemic in metropolitans. In this study, COVID-19 outbreak in The new Region of Beijing was taken as the basic scenario, and a public epidemic outbreak in a metropolis was set up to maintain effective control of the epidemic outside the metropolis. Under such circumstances, how to guarantee the effective supply of FAPs in metropolis is the starting point of this study.

The supply chain of agricultural products includes suppliers, wholesalers, retailers and logistics providers, who have encountered different degrees of difficulties during the epidemic. The purchase of agricultural products is largely dependent on the origin brokers, and the outbreak has led to limited movement of people and great difficulties in purchasing. The transportation link in the logistics is also greatly restricted. Many trading brokers and merchants in wholesale markets of agricultural products are also unable to conduct normal business transactions. These phenomena work together to eventually lead to many chain breaks in agricultural products supply chain and lack of system robustness.

In this study, a three-level supply chain consisting of a single supplier, a single TPL service provider and a single retailer was constructed to guarantee the supply of FAPs in metropolises in the context of COVID-19 epidemic. In this study, on the basis of Stackelberg game theory, a three-level decision-making model of fresh agricultural product supply chain is built to analyze the decision-making process of supply chain members and solve the optimal results under different models. In this study, in addition to the characteristics of FAPs such as easy loss and perishable, COVID-19 epidemic factors such as virus infection coefficient and epidemic prevention efforts were fully integrated into the model to ensure the effective supply of FAPs in metropolitan areas. The main conclusions of this study are as follows.

(i) In the context of COVID-19, the market demand for FAPs in metropolitan areas is negatively correlated with retail prices, and positively correlated with the level of quality control efforts. Compared with the wholesale price of FAPs, the level of 
preservation efforts and epidemic prevention efforts will have a greater impact on the retail price of FAPs in metropolis.

(ii) When the supplier is in the dominant position, the sensitivity coefficient of the quality assurance effort level is positively correlated with the optimal profit of the supplier. Compared with other members, they have stronger control ability and decision-making ability, so that their profits are greater than those of other members. With the improvement of consumers' preference for epidemic prevention efforts and preservation efforts, the profits of the suppliers of FAPs in the supply chain structure under the leading position of supply guarantee will gradually increase.

(iii) Compared with FAPs suppliers in the leading position of guarantee and supply, when FAPs retailers are in the leading position of guarantee and supply, TPL service providers have a higher level of epidemic prevention efforts and preservation efforts for FAPs. At the same time, the quality effort level, market demand and retail price are all greater under the retailer-led guarantee. TPL service providers can only guarantee the supply of FAPs in metropolitan areas in the context of COVID-19 by making higher prevention efforts and preservation efforts than retailers of FAPs.

(iv) When FAPs retailers dominate the guarantee, the profit of TPL service provider has nothing to do with the sensitivity coefficient of the quality assurance effort level. The profit of retailers of FAPs is affected by the sensitivity coefficient of preservation efforts, epidemic prevention efforts and the dominant guarantee status. With the improvement of consumers' preference for epidemic prevention efforts and preservation efforts, the profits of supply chain members in the supply chain structure with FAPs retailers in the leading position of supply guarantee will gradually increase.

The implications of this study are as follows. At the micro level, the broken chain caused by the epidemic shows that to fully ensure the effective supply of fresh agricultural production, it is necessary to infiltrate and participate in the upstream and downstream of the supply chain. Upstream should extend to the supply end, with suppliers of fresh produce developing their own sources of supply. The downstream should strengthen logistics, and the rapid logistics platform needs to be built on a scale. Only when self-run logistics rises to a certain scale can it better reduce costs and increase profits. On the macro level, first of all, the inventory and quality status of fresh agricultural production areas should be sorted out to open up the market of FAPs. Secondly, local government departments should coordinate to open up green channels for such FAPs. Third, logistics resources should be coordinated to ensure that FAPs can reach consumers.

Although this research has achieved the research goal of this paper, there are still some limitations in this paper. Fresh produce suppliers and retailers respectively led the study on fresh produce supply protection in metropolitan areas in the context of COVID-19 outbreak. The guaranteed supply system led by TPL service providers should be studied in the future. In addition, in the context of COVID-19, members of the supply chain for FAPs in metropolitan areas are often one-to-many, many-to-one or many-to-many in reality. In the future, the problem of supply chain game composed of multiple suppliers, multiple TPL service providers and multiple retailers can be considered to ensure the effective supply of FAPs in metropolis.

Author Contributions:Writing—original draft preparation, Y.S.; writing—review and editing, Y.S. and B.L. All authors read and agreed to the published version of the manuscript.

Funding: This research was funded by the Key Projects of The National Social Science Fund of China (19FGLA001), the National Natural Science Foundation of China (71601087), and the Humanities and Social Sciences Planning Projects of Ministry of Education (15YJC630088).

Data Availability Statement: Data sharing not applicables.

Conflicts of Interest: The authors declare no conflicts of interest.. 


\section{References}

[1] Chen, J.Y.; Fan, T.J.; Pan, F. Urban delivery of fresh products with total deterioration value. International Journal of Production Research. 2020, 1828638, DOI: 10.1080/00207543.

[2] Soto-Silva, W.E.; Nadal-Roig, E.; González-Araya, M.C.; Pla-Aragones, L.M. Operational research models applied to the fresh fruit supply chain. European Journal of Operational Research. 2016, 251(2), 345-355.

[3] Blackburn, J.; Scudder, G. Supply chain strategies for perishable products: the case of fresh produce. Production and Operations Management. 2009, 18(2), 129-137.

[4] Cai, X.; Chen, J.; Xiao, Y.; Xu, X. Optimization and coordination of fresh product supply chains with freshness - keeping effort. Production and Operations Management. 2010, 19(3), 261-278.

[5] Cai, X.; Chen, J.; Xiao, Y.; Xu, X.; Yu, G. Fresh-product supply chain management with logistics outsourcing. Omega. 2013, 41(4), $752-765$.

[6] Cai, X.; Zhou, X. Optimal policies for perishable products when transportation to export market is disrupted. Production and Operations Management. 2014, 23(5), 907-923.

[7] Gokarn, S.; Kuthambalayan, T.S. Creating sustainable fresh produce supply chains by managing uncertainties. Journal of Cleaner Production. 2019, 207, 908-919.

[8] He, B.; Gan, X.; Yuan, K. Entry of online presale of fresh produce: A competitive analysis. European Journal of Operational Research. 2019, 272, 339-351.

[9] Jonkman, J.; Barbosa-Póvoa, A.P.; Bloemhof, J.M. Integrating harvesting decisions in the design of agro-food supply chains. European Journal of Operational Research. 2019, 276(1), 247-258.

[10] Ma, X.; Wang, S.; Islam, S.M.; Liu, X. Coordinating a three-echelon FAPs supply chain considering freshness-keeping effort with asymmetric information. Applied Mathematical Modelling. 2019, 67, 337-356.

[11] Mohammadi, H.; Ghazanfari, M.; Pishvaee, M.S.; Teimoury, E. Fresh-product supply chain coordination and waste reduction using a revenue-and-preservation-technology-investmentsharing contract: A real-life case study. Journal of Cleaner Production. $2019,213,262-282$.

[12] Rong, A.; Akkerman, R.; Grunow, M. An optimization approach for managing fresh food quality throughout the supply chain. International Journal of Production Economics. 2011, 131(1), 421-429.

[13] Su, J.; Wu, J.; Liu, C. Research on coordination of fresh produce supply chain in big market sales environment. The Scientific World Journal. 2014, 5, 873980 .

[14] Wu, Q.; Mu, Y.; Feng, Y. Coordinating contracts for fresh product outsourcing logistics channels with power structures. International Journal of Production Economics. 2015, 160, 94-105

[15] Xiao, Y.; Chen, J. Supply chain management of fresh products with producer transportation. Decision Sciences. 2012, 43(5), 785-815.

[16] Yu, Y.; Xiao, T. Pricing and cold-chain service level decisions in a fresh agri-products supply chain with logistics outsourcing. Computers \& Industrial Engineering. 2017, 111, 56-66.

[17] Feng, Y.; Yu, Y.L.; Zhang, Y.Z.; Qian, W.U. Coordination in a three-echelon supply chain of fresh agri-products with TPLSP' s participation in decision-making. Journal of Industrial Engineering and Engineering Management. 2015, 29(4), $213-221$.

[18] Wang, L.; Dan, B. The incentive mechanism for preservation in fresh agricultural supply chain considering consumer utility. Journal of Industrial Engineering and Engineering Management. 2015, 29(1), 200-206.

[19] Xiao, Y.B.; Chen, J., Xu, X.L. Fresh product supply chain coordination under CIF business model with long distance transportation. Systems Engineering-Theory \& Practice. 2008, 28(2), 19-25.

[20] Zheng, Y.T.; Li, J.B.; Chen, Z.Y.; Ming, M.M.; Management, S.O. Optimal decisions of cold chain distributor under uncertain in demand. Journal of Management Sciences in China. 2019, 22(1), 94-106.

[21] Yan, B.; Chen, X.X.; Cai, C.Y.; Guan, S. Supply chain coordination of FAPs based on consumer behavior. Computers \& Operations Research. 2020, 123(11), 105038.

[22] Yan, B.; Fan, J.; Cai, C.Y.; Fang, J. Supply chain coordination of fresh Agri-products based on value loss. Operations Management Research. 2020, 13, 185-196.

[23] Azam, S.M.R.; Ma, H.; Xu, B.; Devi, S.; Zhu, J. Efficacy of ultrasound treatment in the and removal of pesticide residues from fresh vegetables: A review. Trends in Food Science \& Technology. 2020, 97(3), 417-432.

[24] Wang, G.; Ding, P.; Chen, H.;Wu, J. Green fresh product cost sharing contracts considering freshness-keeping effort. Soft Computing. 2020, 24, 2671-2691.

[25] Yan, B.; Liu, G.D.; Zhang, Z.Y.; Yan, C. Optimal financing and operation strategy of fresh agricultural supply chain. Australian Journal of Agricultural and Resource Economics. 2020, 64(3), 776-794. 
[26] Song, Z.; He, S. "Contract coordination of new fresh produce three-layer supply chain". Industrial Management \& Data Systems. 2019, 119(1), 148-169.

[27] Feng, Y.; Wang, Y.F.; Zhang, Y.Z.; Yu, Y.L. Impact of business model on operation of the fresh agri-product supply chain under random output. Systems Engineering - Theory \& Practice. 2020, 40(10), 2631-2647.

[28] Güler, M.G.; Keski, M.E. On coordination under random yield and random demand. Expert Systems with Applications. 2013, 40(9), 3688-3695.

[29] Li, X.; Li, Y.; Cai, X. Double marginalization and coordination in the supply chain with uncertain supply. European Journal of Operational Research. 2013, 226(2), 228-236.

[30] He, Y.; Zhang, J. Random yield supply chain with a yield dependent secondary market. European Journal of Operational Research. 2010, 206(1), 221-230.

[31] Hu, F.; Lim, C.C.; Lu, Z. Coordination of supply chains with a flexible ordering policy under yield and demand uncertainty. International Journal of Production Economics. 2013, 146(2), 686-693.

[32] Xu, G.; Feng, J.; Chen, F.; Wang, H.; Wang, Z. Simulation-based optimization of control policy on multi-echelon inventory system for FAPs. International Journal of Agricultural and Biological Engineering. 2019, 12(2), 184-194.

[33] Birkie, S.E.; Trucco, P. Do not expect others do what you should! Supply chain complexity and mitigation of the ripple effect of disruptions. International Journal of Logs Management. 2020, 31(1), 123-144.

[34] Clausen, J.; Hansen, J.; Larsen, J.; Larsen, A. Disruption Management. OR/MS Today. 2001, 28(5), 40-43.

[35] Huang, C.C.; Yu, G.; Wang, S.; Wang, X.J. Disruption management for supply chain coordination with exponential demand function. Acta Mathematica Sinica. 2006, 26(4), 655-669.

[36] Wu, Z.H.; Chen, H.; Zhao, Q.; Wu, X.Z. Supply chain coordination with demand and purchase cost of retailers disruptions. Chinese Journal of Management Science. 2012, 20(6), 110-117.

[37] Lin, Z.B.; Cai, C.; Xu, B.G. Supply chain coordination with insurance contract. European Journal of Operational Research. 2010, 205(2), 339-345.

[38] Rabbani, M.; Arani, H. V.; Rafiei, H. Option contract application in emergency supply chains. International Journal of Services and Operations. 2015, 20(4), 385-397.

[39] Wang, L.L.; Gao, X.H.; Guo, J. An option contract pricing model of relief material supply chain. Omega. 2012, 40(5), 594-600.

[40] Lodree, E.J.; Taskin, S. An insurance risk management framework for disaster relief and supply chain disruption inventory planning. Journal of the Operational Research Society. 2008, 59(5), 674-684.

[41] Taskin, S.; Lodree, E.J. Inventory decisions for emergency supplies based on hurricane count predictions. International Journal of Production Economics. 2010, 126(1), 66-75.

[42] Saputra, T.Y.; Pots, O.; Smidtdestombes, K.; Smidt-Destombes, K.S.D. The impact of mean time between disasters on inventory pre-positioning strategy. Disaster Prevention and Management. 2015, 24(1), 115-130.

[43] Soleimani, F.; Khamseh, A.A.; Naderi, B. Optimal decisions in a dual-channel supply chain under simultaneous demand and production cost disruptions. Annals of Operations Research. 2016, 243(1-2), 301-321.

[44] Zhang, P.; Xiong, Y.; Xiong, Z.K. Coordination of a dual-channel supply chain after demand or production cost disruptions. International Journal of Production Research. 2014, 53(10), 3141-3160.

[45] Wu, Z.H.; Chen, H.; Zhao, Q. Supply chain disruptions coordination of FAPs under time constraints with quantity discount contracts. Operations Research and Management Science. 2014, 23(03), 146-156.

[46] Qi, X.T.; Bard, J. F.; Yu, G. Supply chain coordination with demand disruption. Omega. 2004, 32(4): $301-312$.

[47] Knoblich, K.; Heavey, C.; Williams, P. Quantitative analysis of semiconductor supply chain contracts with order flexibility under demand uncertainty: A case study. Computers \& Industrial Engineering. 2015, 87, 394-406.

[48] Chen, J.Y.; Maqbool, D.; Hu, Q.H. Flexible procurement contracts for competing retailers. European Journal of Operational Research. 2017, 259(1), 130-142.

[49] Bicer, I.; Hagsoiel, V. Valuing quantity flexibility under supply chain disintermediation risk. International Journal of Production Economics. 2016, 180, 1-15.

[50] He, B.; Yang, Y. Mitigating supply risk:an approach with quantity flexibility procurement. Annals of Operations Research. 2018, 271(2), 599-617.

[51] Nikkhoo, F.; Bozorgi-amiri, A.; Heydari, J. Coordination of relief items procurement in humanitarian logistic based on quantity flexibility contract. International Journal of Disaster Risk Reduction. 2018, 31, 331-340. 